\title{
La formación del dominio político y territorial: del Realengo al Señorío en León
}

\author{
José Avelino Gutiérrez González * \\ Universidad de Oviedo
}

\section{ALGUNAS REFLEXIONES SOBRE EL DOMINIO POLITICO Y LA ARQUEOLOGÍA DEL TERRITORIO}

El objetivo de este artículo es presentar algunas cuestiones sobre la formación del dominio político desde las aportaciones de la arqueología del territorio, tomando como marco espacial y temporal las tierras asturleonesas entre la alta y la baja Edad Media, y como referente más amplio la génesis, implantación y evolución del sistema social feudal.

Frente a una disociación habitual entre una historia (textual) y una arqueología (objetual), el estudio espacial del territorio, con una metodología interdisciplinar y unos planteamientos más ambiciosos que los tradicionales, permite entender de una forma dinámica el proceso de formación e implantación del feudalismo.

Partiendo de la premisa de que una determinada estratificación social tiende a generar una particular jerarquización espacial del poblamiento, la observación de los patrones de asentamiento, la distribución y relaciones entre centros de población, su jerarquización (interna y externa) y sus territorios, deben informarnos sobre la organización socioeconómica del espacio, es decir, sobre la capacidad de organiza- ción de los espacios de trabajo por parte de grupos campesinos (de forma autónoma o subordinada de la producción: destinada al autoabastecimiento o la producción excedentaria, dirigida al intercambio o al pago de una renta) por una parte, así como sobre la capacidad de extracción del excedente por parte de la clase feudal, por la otra, en la medida en que estos procesos "modelan" el paisaje de forma diferenciada y propia de cada formación social, y es por tanto detectable arqueológicamente.

La arqueología territorial del feudalismo debe, por consiguiente, intentar medir el alcance y el proceso de esa jerarquización espacial del poblamiento, campesino y feudal, y de sus respectivas capacidades de organización del trabajo y de implantación de su dominio sobre el territorio o espacio de trabajo de las comunidades campesinas, para valorar la progresiva implantación del sistema feudal.

El concepto de "dominio político", entendido en el sentido restrictivo del medievalismo tradicional como el aparato jurídico-institucional del ejercicio de la potestas o poder "público", puede parecer que desborda los límites de la percepción arqueológica. Sin embargo, entendido en una forma más amplia como manifestación y plasmación del ejercicio de poder, el

* Este trabajo se ha realizado en el marco de los proyectos de investigación "La transición al feudalismo en el espacio galaico-astur-leonés: la reorganización del poblamiento y las estructuras de poder", financiado por el Programa Sectorial de Promoción General del Conocimiento (DGCYT, Ref. PB-97-1327-C03-02) y "Naturaleza y evolución de las estructuras de poder en la primera Edad Media asturiana" (MCYT, DGI, Plan Nacional I+D+I, Ref. BHA2002-04I70-C05-03). 
dominio político tiene un alcance mayor, y se materializa en la capacidad de decisión de un grupo social para organizar un espacio: un espacio de trabajo o término aldeano en el caso de una comunidad campesina, un territorio fiscal, distrito militar, alfoz, dominio, parroquia, obispado, condado, reino, etc, ordenado desde las instancias del poder, y donde se superponen distintas competencias: militar, fiscal, administrativa, religiosa...

Esta consideración nos lleva a plantear si puede denominarse "político" a todo ejercicio o capacidad de organización de un espacio; parece indudable para algunas de las categorías jurídico-institucionales arriba enunciadas (reino, condado, territoria...), más dudoso para las de carácter religioso (parroquia, dominio monástico, obispado), si no fuera porque el dominio que se ejerce sobre ellas sobrepasa lo religioso, y más problemático parece aún para el territorio aldeano. Sin embargo, creo que sí es considerable desde un punto de vista no restrictivo de lo político, del ejercicio del poder como capacidad de decisión y ordenación con autonomía de su territorio, el espacio de trabajo o término aldeano.

Habrá que medir y evaluar esa capacidad y supuesta autonomía campesina de organización de la producción y control sobre el producto; para ello debemos tener presente la posible superposición de poderes sobre el territorio, desde la propia comunidad aldeana, a distintos señores con competencias en el mismo, y discernir cómo se materializa esa concurrencia de poderes, cómo se reflejaría en el "paisaje": en los patrones de asentamiento, en la distribución y jerarquización del poblamiento, en la estructura y ordenación del territorio, en la morfología de los lugares, en determinadas obras, construcciones... Baste recordar, a este propósito, la diversa morfología que adquieren los núcleos formados a partir de -por ejem- plo- sagreras catalanas, granjas monásticas, emplazamientos castrales diversos, o las particularidades de parcelarios y terrazgos ordenados desde diversas instancias e intereses señoriales: dehesas, viñedos, regadíos, montes comunales, etc., o la creación de redes de centros territoriales desde el poder (villanuevas, pueblas...), para darse cuenta de que la ordenación territorial (micro y macroespacial) es un documento con un alto potencial para la interpretación y valoración de la capacidad de los distintos grupos sociales para modificar el paisaje y trascender en él su estructura política, administrativa y socioeconómica.

En términos arqueológicos, esto implica no sólo restringir el análisis a la "Arqueología del Estado", la "arqueología del poder" (centros de poder: castillos, palacios, iglesias...), o más bien considerar ésta como el resultado de la organización social sobre el "paisaje", y analizar a través de éste las condiciones de trabajo, las relaciones sociales de producción, en suma, la propia organización socioeconómica.

Conforme a las premisas enunciadas la arqueología del feudalismo debería intentar detectar la capacidad y autonomía del campesinado para:

- organizar su trabajo y construir su territorio: límites, distribución interna de la tierra: dedicación especializada o complementaria,

- regular la forma o régimen de explotación: ¿colectivo o familiar?, ¿régimen de propiedad y explotación autónomo -colectivo o privado-, subsidiario o dependiente?

- y en definitiva: organizar una producción de subsistencia -autosuficiente- o excendentaria: destinada al mercado o a pagar una renta!

Una mayor autonomía e independencia de los grupos campesinos en un estadio prefeu-

\footnotetext{
I Sobre estos aspectos del análisis arqueológico del territorio: términos campesinos, arqueología de los límites, amojonamientos, campos fósiles, etc, vid. como referencia Gutiérrez (200I), además de la nota siguiente. Sobre la construcción de un territorio prefeudal (la comunidad castreña de Valdoré, en las montaña leonesa) anterior a la presura de Purello a mediados del siglo IX y la progresiva implantación e integración en un territorio feudal (la mandación de los Flaínez) vid. Gutiérrez (200l).
} 
dal ${ }^{2}$ respecto a poderes externos (Estado, señores...) generaría tendencias hacia un poblamiento disperso (castros, aldeas, cabañas...), una dedicación básicamente autosuficiente y complementaria, con un territorio de explotación mixto, no especializado, régimen de propiedad comunal y trabajo colectivo, adaptado a, y por, las condiciones de su fuerza de trabajo, su estructura familiar y estratificación social, así como a los condicionamientos medioambientales; $y$, en tercer lugar, una ergología "no clásica", "pobre", propia de una producción de subsistencia y unas débiles relaciones de distribución y mercado: construcciones campesinas sencillas, sin edilicia señorial, sin mobiliario de "lujo", sin moneda... A este perfil - considerado "empobrecido", decadente", "oscuro", "indefinido" bajo los parámetros de la arqueología clásica y "desarticulado", "inestable", "arcaizante" para el medievalismo textual o sencillamente invisible y opaco para la detección habitual- responden la mayoría de los poblados campesinos que hemos localizado adscribibles a esos "tiempos oscuros", prefeudales: antiguos castros recurrentemente utilizados en época tardoantigua-altomedieval, sin reconstrucciones importantes de defensas, carentes de estructuras señoriales (torres, palatia...), iglesias, etc.; o sencillos y casi imperceptibles fondos de cabañas de "filiación" quasi-protohistórica, a los que se asocian frecuentemente cuevas, hoyos y silos de pequeñas dimensiones, destinados a almacenamiento de productos y sementera, que indican un cierto control de la producción y por tanto ausencia de captura de excedentes.

En segunda instancia, deberíamos contrastar la capacidad de los poderes feudales para generar, en primer lugar, centros de poder, de dominación, de organización político-administrativa y militar, de control y ordenación de la producción (centros territoriales, cabezas de alfoz, castros, castillos, palatia...) y de encua- dramiento ideológico-religioso de la población (centros de culto, iglesias, monasterios,...).

La presencia de centros de poder evidencia el éxito de la conquista feudal, su capacidad para imponerse al campesinado y para imponer su jerarquización social-territorial, su "poder político". Su presencia, morfología y dinámica (tipología y evolución crono-espacial de fortificaciones, centros de culto, villas concentradas) muestra y mide el proceso, formación y evolución de la implantación del feudalismo, así como quiénes son los agentes dominantes: rey, señores, concejos...

Su ausencia (y la de otros indicadores como los documentos escritos) indica no "crisis", "decadencia", "contracción de la producción", "pobreza”, "despoblación”, "desorganización”, "desorganización", "inestabilidad", etc. (en términos del medievalismo tradicional), sino la incapacidad señorial para capturar el excedente de la producción agraria y para generar una "arqueología del poder" (edilicia y mobiliario "rico", "de lujo", "bueno"...) y un registro escrito del poder (un aparato jurídico-institucional, el registro notarial de derechos de propiedad y legitimación del poder: expresados en crónicas, fueros, compra-ventas, sanciones...).

En segundo lugar, para generar una ordenación territorial jerarquizada (reino, condados, distritos, territoria, mandationes, tenencias, alfoces, concejos, dominios, estructura administrativa eclesiástica: diócesis, arciprestazgos, parroquias...) y unas determinadas relaciones centro/periferia, con un poblamiento campesino subordinado a unas poblaciones con funciones rectoras concentradas (villanuevas, pueblas, ciudades...).

Al mismo tiempo, en tercer lugar, debemos intentar ver la capacidad para mejorar la captura del excedente, la renta feudal, poder eco-

\footnotetext{
2 Me refiero, como expuse al principio, al marco espacial y cronológico de los pueblos norteños en la época de transición del mundo antiguo al feudal (siglos $\mathrm{V}$-X), en la que la presión exterior (estatal) es menor que bajo el periodo imperial romano o lo será después, en el reino asturleonés. Tomo como referencia para estas reflexiones algunos trabajos empíricos y teóricos anteriores (Gutiérrez 1985, 1989, 1995, 1996, 1997, 2000, entre otros).
} 
nómico que conduce también a obtener más poder político. Sus mecanismos son más o menos conocidos:

- concentración de población (villas nuevas reales, pueblas, ciudades, castillos, castros o recintos fortificados) para contrarrestar las tendencias al poblamiento disperso prefeudal, altomedieval. Los objetivos de esta acción señorial son asegurar y controlar la producción, mediante una población aldeana subordinada y unas tierras agrupadas (el alfoz concejil), unas actividades mercantiles e industriales concentradas, una regulación de la explotación: contratos y fueros; con ello se pretende asegurar, concentrar y aumentar la renta (sobre la producción agraria, industrial y comercial).

- intromisión en la organización e intensificación de la producción, lo que supone la ruptura de la autonomía campesina, mediante la promoción e inducción de roturaciones y deforestaciones; la inducción o imposición de cultivos excedentarios (cereal, vid, ganadería especializada); la apropiación de medios de producción, por ejemplo, mediante una participación inicial en divisas (montes y pastos), suertes (lotes de tierra, riegos), o veces (molinos) para ir aumentando la intromisión mediante la adquisición de tierras, montes, pastos o recursos energéticos (agua, minas, salinas...) (PASTOR 1980); la apropiación de fuerza de producción, mediante el trabajo dependiente, e imposición de régimen de explotación/relaciones sociales de producción (servidumbre, colonos, arrendamientos...) y el control fiscal y judicial de la producción; la mejora de los sistemas técnicos de producción y transformación (molinos señoriales, aceñas, ferrerías hidráulicas...); de almacenamiento del excedente (anulación silos y bodegas familiares y creación de graneros, celleros, bodegas señoriales en castillos, palacios, monasterios, villas o ciudades; de circulación del excedente (mejora de vías, puentes, portazgos...); de monetización del excedente y la renta (acuñación moneda, exigencia de renta en moneda).
Como puede comprenderse fácilmente, estas iniciativas señoriales tienden a modificar radicalmente los patrones de asentamientos, la distribución y relaciones entre poblados y grupos sociales, las relación de éstos con sus espacios de trabajo; es decir, la organización de la producción y las relaciones sociales de producción.

También en relación con esta dinámica, encontraríamos un tercer mecanismo o instrumento de optimación de la captación de renta: la eliminación de la "competencia" en la producción y captura del excedente, tanto campesina (mediante la creación de dehesas, cotos, monopolios...) como feudal (fortalecimiento del realengo: creación de concejos, frente a dominios de otros señoríos laicos o eclesiásticos, lo que supone la plenitud de las monarquías feudales).

A partir de las líneas trazadas, creo que el análisis arqueológico del "territorio feudal" puede reflejar y ayudar a comprender la dinámica de la formación social, generada por el particular modo de apropiación del excedente y el modo de expresar el dominio político: es decir, la jerarquización social expresada en una organización espacial/territorial jerarquizada y ordenada.

Estas líneas de actuación en la arqueología territorial del feudalismo encuentran, sin embargo, no pocas dificultades y limitaciones, tanto en la detección como en la interpretación. La información y caracterización del proceso y funcionamiento de la implantación feudal ha sido elaborada tradicionalmente desde las fuentes escritas, igualmente limitadas y sesgadas, mientas que la arqueología, hasta los tiempos más recientes, se ha limitado a un ejercicio ilustrador, objetual y subsidiario del discurso literario, sin concurrir en la elaboración de la teoría histórica. Las fuentes escritas - emanadas desde los poderes feudales- apenas registran lo que se encuentra más allá de la propia acción señorial, por lo que grandes áreas o pequeños poblados campesinos, ajenos a ella (en los primeros tiempos medievales) resultan "invisibles" y silenciados en el registro escrito; el estadio prefeudal es totalmente imperceptible desde 
estas fuentes. Para conocer mejor la génesis del proceso se impone la concurrencia de una arqueología con una intención social, desprovista del normativismo clásico, y más atenta a la dinámica de las transformaciones estructurales desde la Antigüedad en el poblamiento, la producción, la organización social.

Sin embargo la metodología y el bagaje empírico de la arqueología espacial, territorial, agraria, de la producción, es aún escaso y limitado. Además no puede ser una metodología insensible a la información procedente del registro escrito; hay aspectos de interés para su propósito accesibles desde -que no únicamente- éste, como los límites de los territorios, las condiciones sociales de trabajo, el régimen y organización de las explotaciones, etc. El registro arqueológico no entra en competencia con una gran parte de la información escrita, pero sí concurre, y debe hacerlo, en la construcción global de la interpretación histórica, aportando tanto las evidencias intangibles desde aquella como contrastando y corrigiendo las carencias, limitaciones, tergiversaciones 0 manipulaciones en que puede incurrir el medievalismo textual. En lo que la arqueología debe tomar la delantera en el discurso histórico es en el estudio de los elementos materiales, ya señalados, de implantación y gestión del dominio político feudal.

En la detección existen unos aspectos más evidentes como la localización e identificación de los centros de poder (fortificaciones, centros de culto...); son los más evidentes, por su privilegiado emplazamiento y topografía, su edilicia, etc. Es la arqueología más habitual, aunque frecuentemente descontextualizada de su papel en la cadena social.

Podemos también enumerar algunos otros aspectos fácilmente reconocibles:

- la concentración de población (en plena Edad Media): villas nuevas o pueblas reales; la imposición de castillos, palacios, iglesias, monasterios en ellas; o la reordenación y reconstrucción de antiguos castros e iglesias prefeudales.
- los cultivos inducidos (por ejemplo.: introducción de la vid en zonas poco aptas).

- el control de la energía (aceñas y grandes molinos señoriales incluso fortificados; minas, salinas o puertos controlados por castillos...)

- los sistemas de almacenamiento feudal: anulación y amortización de silos domésticos, cuevas-refugio, cuevas-silos, graneros y bodegas señoriales, etc.

Pero también hay otros aspectos menos evidentes o más intangibles. Las dificultades y limitaciones para detectar arqueológicamente las características y acciones para la construcción del "territorio feudal" (especialmente el fiscal: el dominio, la gran propiedad) por su dispersión, obliga a relativizar la autonomía del análisis arqueológico y su complementariedad (que no subordinación) con el registro literario.

Para ello podemos efectuar una "lectura arqueológica" de la documentación escrita (mediante contraste empírico, arqueológico) sobre fronteras, límites de distritos y circunscripciones, etc.; o identificar los centros territoriales (cabezas de alfoz, villas, ciudades...). Ahora bien, para la percepción de los límites de los "territorios feudales": ipodemos aplicar la metodología de análisis espacial: relaciones centro/periferia, teoría de los lugares centrales...? o-por el contrario- es preciso contrastar fórmulas teóricas con registro empírico y documentación escrita.

Otro problema es la superposición y concurrencia de poderes y facultades (campesinas y señoriales) dentro y fuera de la aldea y el territorio campesino, sobre el que actúan, interfieren y se superponen distintas jurisdicciones (propiedad y derechos campesinos, parroquiales, episcopales, monásticos, realengos, magnaticios, etc.); ¿cómo afecta eso al registro arqueológico?, ¿es posible detectarlo? E igualmente, ¿es posible delimitar y reconocer una ergología peculiar del dominio feudal (magnaticio, monástico, de realengo)? El dominio feudal puede estar concentrado, disperso, no es está- 
tico, es transferible; en ocasiones puede ser difícil, también, diferenciar el centro de poder de un dominio (explotación económica señorial o dominical), o de una mandación (circunscripción política "pública"). Es preciso considerar que el dominio no crea un territorio delimitado, "cerrado", un "término", sino que actúa sobre unas comunidades campesinas que, generalmente o más frecuentemente, sí tienen su territorio - su término- delimitado (en cierta forma así protegido o defendido). Lo que sí pueden observarse son las tendencias generales y homogéneas en todo el reino (distribución de fortificaciones, palatia, etc), lo que puede indicar una acción central, regia, y su alcance.

Algunos otros problemas más surgen al paso de estas reflexiones; por ejemplo, los castros altomedievales, ise deben a comunidades campesinas autónomas? ¿o a una jerarquización social interna de dichas comunidades?; o, ¿cómo atribuir al trabajo campesino o a la iniciativa señorial la creación de nuevos poblados altoplenomedievales, las roturaciones, dehesas, términos y parcelarios del mismo periodo, la arqueología de la trashumancia, etc?

En definitiva, detrás de todos estos planteamientos e interrogantes sobre el territorio y su control, subyacen cuestiones más generales sobre un posible estadio prefeudal, un campesinado autónomo previo al avance feudal, el origen de dicho proceso de formación y de la misma clase feudal (aristocracia tardoantigua, visigótica, jefaturas locales...).

Concretamente, el crecimiento agrario campesino que comenzamos a caracterizar en los siglos VIII-IX en diversas áreas del norte peninsular (por ejemplo: poblamiento disperso, poco jerarquizado, asociado a inicio de roturaciones, organización de comunidades en valles-territorios-alfoces), ies un proceso de autonomía campesina prefeudal?, ¿cuáles son sus causas: el desarrollo de fuerzas productivas y aumento demográfico, la liberación de fuerzas de producción en ausencia de control señorial? o por el contrario, ¿indicaría el comienzo de los dominios y la presión señorial?
Creo que el proceso de este avance viene dado por los indicadores (arqueológicos y literarios) mencionados (percepción progresivamente -desde el siglo X- más evidente de centros de poder, jerarquización poblacional y territorial, registro escrito, etc.), cuyo aumento marca el ritmo de la progresiva implantación del feudalismo.

Sin embargo es preciso tomar algunas precauciones. Las interpretaciones de los medievalistas (sobre el registro escrito) acerca de estas cuestiones son sumamente contradictorias e insatisfactorias; por ejemplo las teorías de Sánchez-Albornoz a partir del presupuesto de la "despoblación" y la "repoblación" como premisa de la generación de un campesinado independiente y ausencia de feudalismo; o las de Barbero y Vigil sobre la premisa de la perduración de unas estructuras sociales primitivas, indígenas, gentilicias, en cuya ruptura de cohesiones de parentesco se encontraría el origen de las jefaturas y progresiva feudalización; o de García de Cortázar desde posturas más eclécticas e integradoras, apoyadas en la "aculturación" meridional, etc.

En mi opinión, estos estudios evidencian un importante déficit empírico debido al desconocimiento de las estructuras materiales del poblamiento y la sociedad medieval y premedieval, pre-documental. Algunos trabajos más recientes, que integran el registro arqueológico tardoantiguo (Martín Viso, Pastor Díaz de Garayo, etc), acusan problemas de encajar unos datos obtenidos sin interrogantes o planteamientos sobre estas cuestiones.

Por el contrario, una gran parte de los trabajos arqueológicos suman a las dificultades y las limitaciones para obtener respuestas complejas una ausencia de planteamientos teóricos propios, no subordinados a las premisas de los medievalistas (Sánchez-Albornoz, Barbero y Vigil, principalmente); la arqueología del feudalismo manifiesta un importante déficit teórico para proponer, ya no "modelos", sino algunas "pautas" para la interpretación de la organización social prefeudal (para época predocumental o premedieval y feudal). 


\section{DEL REALENGO AL SEÑORIO. UN EJEMPLO EN TIERRAS LEONESAS: LAGUNA DE NEGRILLOS}

La arqueología del territorio, contrastando la información escrita, puede aportar importantes conocimientos históricos a la formación de las estructuras de poder. Como ejemplo de aplicación empírica, podemos seleccionar un espacio abarcable desde ambos registros.

La villa de Laguna de Negrillos, con su alfoz, fortificaciones y morfología urbana, ejemplifica de manera muy expresiva la evolución -muy generalizada en el norte peninsular- de una aldea campesina en la Edad Media, surgida de la colonización de la Meseta en los primeros tiempos medievales; más tarde "poblada", es decir reorganizada y dotada con nuevas funciones políticas, jurídicas, militares y socioeconómicas, por Alfonso IX en el siglo Xll, pasando a desempeñar un papel más activo en la política y el señorío regio, para caer integrada, en la baja Edad Media, en el señorío de uno de los linajes nobiliares más destacados del reino.

\section{El medio físico}

Laguna de Negrillos se encuentra en el Bajo Páramo leonés (Fig. I), una meseta en torno a los 780 metros de altitud en el interfluvio EslaÓrbigo comprendida aproximadamente entre el triángulo que forman León-Benavente-Hospital de Órbigo. Las terrazas de esta meseta están compuestas por depósitos pliocuaternarios con una litología de cantos cuarcíticos con matriz de arcillas y limos. Esta llanura fue modelada por los abundantes arroyos y regatos que lo surcan drenando las aguas superficiales hacia el río Órbigo. Destacan, además, las frecuentes lagunas endorreicas que se reparten en su entorno algunas de las cuales aparecen ya mencionadas en los documentos medievales Bajo el suelo se encuentra un gran acuífero que posibilitó la perforación de un gran número de pozos artesianos; las frías y pedregosas tierras silíceas pudieron con ellos dedicarse a cultivos cerealícolas, hortícolas y de leguminosas, además de viñedos y algunos frutales. Las relictas manchas arbóreas de encinar, que hacían del "monte" una importante fuente de recur- sos energéticos y alimenticios, han ido desapareciendo ante la extensión agrícola de los últimos tiempos.

\section{Los tiempos precedentes}

La mayor parte de este Páramo tuvo una baja densidad de ocupación en tiempos antiguos (Fig. 2). Los asentamientos castreños prerromanos se encuentran preferentemente en altozanos y cerros próximos a los grandes valles y vegas de los ríos Esla y Órbigo, habiendo quedado el páramo interfluvial dedicado a bosque, de donde extraerían un importante caudal de energía y productos silvícolas (madera, frutos, caza..., a juzgar por los análisis antracólogicos y faunísticos realizados en nuestras excavaciones en el castro de Valencia de don Juan).

En época romana fueron también las fértiles vegas y terrazas fluviales las principales áreas de asentamiento y explotación agraria, bien ocupando algunos castros anteriores que son elevados a la categoría de civitates (como Valencia de don Juan -Comeniaca-, San Martín de Torres -Bedunia- o Fuentes de Ropel -Brigaecium-) o bien implantando villae y otras pequeñas explotaciones agrarias en las mejores terrazas del Esla y del Órbigo.

Las tierras altas del Páramo registran, en cambio, una escasa población en esos momentos antiguos, registrándose tan sólo un asentamiento romano en Audanzas del Valle, unos kilómetros al sur de Laguna de Negrillos. Una gran parte de las mismas estaría ocupada por monte bajo (básicamente encinar), donde se desarrollarían actividades cinegéticas a las que se refiere alguna inscripción romana de Legio (León) como la conocida ara consagrada a Diana por el legado augustal Quinto Tullio Maximo (162166) que se vanagloria de sus dotes venatorias dando caza a cabras, ciervos, caballos y jabalíes "in parami aequore" (CIL, II, n²660).

\section{La alta Edad Media. La colonización agraria del Páramo leonés}

No parece, pues, que haya sido hasta la temprana Edad Media cuando -de una manera progresiva- se produjera el proceso coloni- 
zador y poblador de estas tierras del bajo Páramo leonés, en el entorno donde se originaría la villa de Laguna ${ }^{3}$.

Desde comienzos del siglo $X$ y partiendo de norte a sur desde la ciudad de Legio -por entonces convertida en la nueva capital del reino asturleonés- van apareciendo, a juzgar por la documentación coetánea, algunos pequeños centros monásticos y "villas" de propiedad magnaticia (condes, obispos, familia regia) que se van haciendo con el dominio de hombres, tierras y bienes raíces -ya puestos en explotación previamente por comunidades campesinasen un extenso páramo a colonizar ${ }^{4}$.

Uno de estos primeros centros de organización y colonización agraria sería el pequeño núcleo cenobítico de Valdevimbre, que a lo largo de la décima centuria va apropiándose de "villas" campesinas con tierras, prados, viñas, molinos, aguas y acueductos en su entorno, en las riberas de los ríos Bernesga, Torío y Esla ${ }^{5}$. Sin embargo, los documentos muestran no el surgimiento de las explotaciones agrarias, sino el comienzo y los fundamentos de la posesión feudal de tierras y hombres que ya están allí instalados y han organizado y puesto en explotación esas tierras. Hasta entonces los diplomas -refrendos jurídicos de esas aprehensionessilencian la existencia de las aldeas y comunidades campesinas, que habrían ido surgiendo y colonizando el Páramo en los tiempos pre- cedentes, aún indefinidos. De suponer un vacío demográfico total hasta entonces carecerían de sentido las alusiones a adquisiciones y pleitos por el control de aguas, molinos, "villas" y tierras ya puestas en cultivo. Uno de los primeros y más expresivos documentos de adquisición de tierras y de la progresiva apropiación y entrada en dependencia (jurídica y tributaria) de los hombres del Páramo lo constituye la donación que Ordoño III hacía en el $9 \mid 8$ al abad Belderedo y monjes de Santiago de Valdevimbre del lugar de Busto (Bustillo del Páramo) que habían "aprehendido" en tiempos de Alfonso III, con sus pertenencias y todos sus hombres, que quedarían bajo su obediencia y tributación 6 .

En las primeras décadas de la centuria se crearía también, en las cercanías de Valdevimbre, y no sin disputas con aquel monasterio, otro centro cenobítico, el de los Santos Justo y Pastor en el valle de Ardón, "in territorio legionense", inicialmente en Cillanueva y posteriormente -en la segunda mitad del siglotambién en "Rozuela", convirtiéndose en un solo monasterio con dos casas o cenobios ${ }^{7}$. Al abrigo del castro de Ardón, importante centro político y militar al tiempo que constante referencia territorial de las tierras del entorno ${ }^{8}$, el abad y la comunidad van adquiriendo a lo largo del siglo $X$ un buen número de tierras, heredades y otros bienes en los campos del Esla y en el Páramo?.

\footnotetext{
3 Aún en pleno siglo X son frecuentes las referencias documentales al "monte", por ejemplo: en el 965 se delimita una tierra en Fontecha "de termino (...) de carale antiqua de ualle usque in monte" (SER 1981, doc. n'. 123).).

4 Vid. un estudio más extenso de este proceso de Gutiérrez (1996).

5 El primer documento conocido de este cenobio data del 9/5, alusivo a un pleito entre el abad y monasterio con otros propietarios sobre las aguas del río Bernesga que movían los molinos del cenobio (SÁEZ 1987, doc. n 34). Sucesivos diplomas entre el 918 y 978 (Vid. Ib., doc. n. 45, 47, 6I, II 5, I25, I28, I44, I55, I59, 227, 244, y SÁEZ \& SÁEZ, 1990 doc. n. 334, 365, 366, 4I0, 454) recogen donaciones y adquisiciones del monasterio de Valdevimbre en lugares del entorno como Bustillo del Páramo (año 918), Valdesaz de los Oteros (937), Vega de Infanzones (937), Valdevimbre (942 y 963), Ardón (950), los Oteros (952) y Oncina (978).

6 SÁEZ 1987, doc. $n^{\circ} 45$.

7 Vid. en Rodríguez (1964) la historia y documentación de este cenobio altomedieval, el proceso de adquisición de bienes y su papel en la organización y colonización del territorio circundante. No obstante, muchas de sus afirmaciones e interpretaciones son controvertidas y ampliamente contestadas (SER 1981, pp. 30-32; SÁEZ 1987, XXXI y p. 106).

8 Sobre las funciones del "Kastrum", "Castellum" u "Oppidum Ardon" en este proceso expansivo de colonización y apropiación de tierras y poblaciones puede verse Gutiérrez (1995, pp. 184-187).

9 El primer documento original y auténtico que nos informa del monasterio de Ardón y de sus adquisiciones es, así, el del 932 (RODRÍGUEZ 1964, doc. n. II; SÁEZ 1987, doc. n. 93) según el cual el monasterio recibía en donación de un presbítero varias heredades, "casas, terras, uineas, ortos, pomaris, siue pratis", en "Matella" y "Morella", "sub urbio territorio legionense, discurrente cale a Coanca" (Coyan-
} 
Otros centros monásticos leoneses, como el monasterio de Santiago de León, se hacen también -desde comienzos del siglo $X$ - con diversas explotaciones campesinas en el Páramo, al sur de la ciudad de León ${ }^{10}$.

Junto a estos agentes colonizadores van también apropiándose de los hombres, villas y tierras del Páramo los grandes poderes magnaticios de la corte, como los obispos, reyes y condes. El obispo legionense es uno de los principales detentadores de bienes en el territorio leonés, de mayores dimensiones y más rápida y poderosa adquisición y formación de dominios, en los que no sólo entran a formar parte bienes raíces y muebles sino también campesinos, que adquieren obligaciones jurídi- cas y de pagos en especie (cebada, lino, rejas de hierro) con los nuevos señores ".

Los propios reyes leoneses, la familia real y algunos magnates próximos a la corte ${ }^{12}$ participan, si no encabezan, este proceso de apropiación de bienes en el Páramo por esta época.

Paralelamente se intensifica la ocupación y organización agraria del Páramo por un buen número de hombres y mujeres que no forman parte de grupos poderosos; parece tratarse de familias campesinas con plena capacidad jurídica de actuar, poseer, comprar, vender y organizarse en concejos aldeanos, al margen de la presión feudal, al menos en los momentos iniciales del proceso colonizador ${ }^{13}$. Precisamen-

za, Valencia de don Juan). Según otros diplomas del Archivo catedralicio leonés, entre el 939 y el 1087 el monasterio de Ardón adquiere, por compra o donaciones, otros muchos bienes raíces en el entorno, "iusta Kastrum Ardon", en "Ualle de Mahmute", "iusta fratres", en Valdevimbre, Oncina, Oteros, valle del Esla y algunos otros en el Cea (Vid. SÁEZ 1987, doc. n. 93, I I8, I I9, etc; SÁEZ \& SÁEZ 1990, doc. n. 266, 267, 269, etc; RODRÍGUEZ 1964, doc. n. II-XCII). Finalmente, el monasterio con sus dos centros de Cillanueva y "Rozuela", fueron donados a la mesa capitular catedralicia de León en I I 6 por el obispo Diego (RODRÍGUEZ I964, p. 50 y doc. $n^{\circ}$. XCIII).

10 En el 917 el abad Yquilani donaba a la congregación del monasterio de Santiago, entre otros bienes, "in alio loco que uocitant Uncina corte conclusa, cum suas kasas, terras, uineas, pratis, ortalibus et suo lagare... Adicio etiam in Berzianos, in Paramo, uillas tres: de parte de Mata de Rege, termino de Hamiloco, et alia pars termino de Fontecta, et tertia pars termino de Roiolos; ipsas uillas, cum homines abitantes et qui ad abitandum uenerint, ad uestram concurrant precepta, patrocinium uobis sit prebeant et obsequium, sicut eas iuri meo abui possessas..." (SÁEZ 1987, doc. n. 42). En 1012 adquirían la villa de San Esteban, en territorio astoricense, con términos de Villademor, Grajal, Cabañeros y La Antigua, lugares próximos a Laguna (RUIZ ASENCIO 1987, doc. n. 709).

II En el año 917 -si es que no se trata de un documento manipulado, a juzgar por algunos detalles y fórmulas comunes a diplomas posteriores- el obispo Frunimio concedía a la iglesia de León "cortes", huertas, tierras y villas en León y sus proximidades, además de "alia uilla in Urbeco que uocitant Uerzeianos, cum terras et pomiferis, linares, montes, fontes, exitos, limites, terras cultas et incultas... cum omines auitantes, uel qui abitare uenerint, reddant uobis per singulos annos XII modios de ordeo, et XII uizinarios de lino et VI relias..." (SER 1981, doc. n. 10; SÁEZ, 1987, doc. n. 43), además de Bercianos del Páramo -situado a 16 km. al norte de Laguna- concede también otras villas, junto con "duos pueros qui custodiebant uakas C et oues C", "in Paramo tras Extola", es decir en la margen izquierda del río Esla, significativa percepción del espacio aún poco articulado y "ordenado". Por entonces, todo este territorio al sur de la ciudad de León, entre ésta y Coyanza (Valencia de don Juan), es también -y principalmente- denominado "suburbio territorio legionense, discurrente cale a Coanca" (RODRíGUEZ 1964, doc. n. II, SÁEZ 1987, doc. n. 93, año 932). Poco después parece haberse ido discriminando el concepto territorial del "Páramo", restringiéndose al espacio que aquí tratamos, interfluvio EslaÓrbigo: "...in Paramo... in loco predicto ubi dicent Bustello", recibía una villa el obispo Froilán de manos de la reina Elvira y su hijo Alfonso V (SER 1981, doc. n. 51, año 1000).

12 En el año 989 Bermudo II concedía a Muño Fernández su villa "iuri nostro deuitam" de Toral (hoy Toral de los Guzmanes, cercano a Laguna) en "territorio Couianca in regionem Cantabrie, secus fluuio Estola", con sus términos y población con sus prestaciones y obligaciones (SER 198I, doc. n. I56). En el año 1000 -según el ya mencionado diploma del archivo catedralicio leonés (Ib., doc. n. 5 I)- la reina Elvira y su hijo Alonso $(V)$ donaban al obispo legionense una heredad o "villa" en el lugar de Bustillo del Páramo, que habría sido de Bermudo Uzzariz "iuri quieto". Vid. también la donación de Ordoño III y Urraca en el 956 al presbítero Berulfo y monjas del monasterio de Ardón de varias "villas" que habían pertenecido antes a otros grandes propietarios (SÁEZ \& SÁEZ I990, doc. $n^{\circ}$. 298). Añádanse también algunos testimonios documentales más, como por ejemplo, la extensa donación que en el 994 hace Bermudo II a Fernando Núñez, a cambio de un caballo valorado en CCC solidos, de "Uillas Kazanocos et Ualle de Menini qui sunt in territorio de Ualle de Sancta Maria semper uirginis Antiqua, prope flumen Urbigo. Leuase ille termino de illa uilla de Sancta Maria usque in termino de Villa Maiore et inde concludit ad termino de Uilla Strigo et circiter giro de termino de Continis, et ex alia parte de Bustello et de Aquilar, et inde uadit ad terminum Audanensis et uenit ad termino de Gradanes" (RUIZ ASENCIO I987, doc. n. 565). Cazanuecos, La Antigua, Villamor de Laguna, Villaestrigo, Audanzas y Grajal son lugares inmediatos al suroeste de Laguna de Negrillos.

13 En el 926 Lupo y su hijo Godesteo venden a Yaha Yucef, siervo de Lazaro Tello, su "villa" "in ualle de Fontecta" delimitada por los términos de otros campesinos: Abandonus, Cimas, Uenze y el propio siervo (i); la venden con viñas, casas, cebada y otras posesiones por veinticinco sueldos y una cuba. Confirman Halifa, Emer, Omar, Fortes, Alite, Gondisalvo, Abduce y Apilia (SÁEZ I987, doc. $\left.n^{\circ} .7 \mathrm{I}\right)$. En el 940 Mohnoya y doña Ego adquieren a Leon, su mujer Guntenibia, Mahmute y su mujer lusta, unas tierras en el 
te entre estos personajes que adquieren bienes, trabajan las tierras y efectúan "pobladuras" aparecen algunos con nombres mozárabes o arabizados 14; algunos de ellos proporcionaron su onomástica a un buen número de lugares del Páramo ${ }^{15}$, donde abundan junto a otros expresivos de diferentes procedencias ${ }^{16}$.

\section{Origen de Laguna}

La primera mención documental de Laguna de Negrillos aparece en el año 905 17, aunque su contenido deba referirse a una época posterior; según el diploma Alfonso III habría hecho unas extensas donaciones a la iglesia de Oviedo en Asturias y León, entre ellas iglesias y tierras en la Valdoncina (páramos inmediatos al suroeste de la capital leonesa) y en "territorio Coianka uillam quam dicunt Sancti Emilia- ni que ab antiquis nocebatur Sanctos Medianos ex integro, per suos terminos et locos antiquos, per terminos Sancti Uicentii et Uilla Mannam et per Zuares et per Lagunam et ex alia parte per flumen Estula cum sexigas molinarias, siue et piscarias, prata, pascua, exitus, fontes...". Sin poder descartarse completamente una base preexistente sobre la que se manipularía el documento, en cualquier caso se confirma la existencia de Laguna y las cercanas villas de Zuares, Villamañán, San Vicente y San Millán en momentos anteriores al siglo XII; seguramente en un momento avanzado del siglo $X$, a juzgar por el mencionado proceso colonizador del Páramo ${ }^{18}$.

El lugar de Laguna probablemente se habría ido desarrollando a lo largo del siglo $\mathrm{XI}$ en las proximidades del monasterio de Negrillos $^{19}$, un

Torío y otras porciones de tierras, molinos, huertos y viñas en Fontecha (SÁEZ, 1987, doc. n. I39). En el 965 (SER I98I, doc. n. 123) "in concilio Sancti Stefani" (San Esteban de Villacalbiel, al norte de Laguna) Foracasas, Salvador y Ramón, venden libremente, "placuit nobis et ita accesit voluntas, caro animo et prona voluntas, ut uinderemus tibi Aiube et uxor tua Caboana terra nostra propia quem abemus in Ualle de Fonte(tecta) in conlationis de Uilla Abcalbelle: de termino Doneiane usque in termino de Aiube...". En el 994 (Ib., doc. $n^{\circ}$. I64) Maior y Xaba cambian a Monio Fernández y su mujer Elvira una viña "in Ual de Uimen ic in Uilla Loba(r) in loco predicto Ualbona...". No obstante, su número entre tantas otras propiedades y acciones apropiadoras magnaticias, obliga a relativizar las vehementes afirmaciones de Claudio Sánchez-Albornoz (1966, 1976, etc.) respecto a la "gran masa de pequeños propietarios libres" en León y Castilla.

14 Aiube o Aiub, Abcalbelle, Xaba, Foracasas, Mazarefe y otros mencionados en las notas anteriores (Vid.. también Ser, I98I, doc. $\mathrm{n}^{\circ}$. $6,51,123,164$, etc.). Sin que pueda asegurarse certeramente su origen mozárabe, consta la participación de este colectivo en la colonización de tierras leonesas (Vid. RODRÍGUEZ 1972, 1982, MERINO 1979) y de Tierra de Campos (MARTíNEZ SOPENA 1985), aunque posiblemente haya sido sobrevalorada excesivamente.

15 Además de Fontecha, "uilla Abcalbelle" (Villacalbiel) y otros mencionados arriba, los hombres "ex progenie Mazarefis" participaron en las supuestas "populaturas" de Berulfo en el Páramo más próximo a León (SER 198I, doc. n. 6); Villar de Mazarife (ya documentado en el año 1000, lb. doc. $n^{\circ}$. 5I) se encuentra unos kilómetros al suroeste de la capital legionense. En las cercanías se fijaron otros topónimos de un origen posiblemente semejante: Mozóndiga, Méizara, Banuncias, Benazolve, Benamariel, Algadefe, Villacalbiel, etc. Quedaría por determinar su cronología y adscripción sociocultural o étnica, así como las relaciones sociales y posición socioeconómica de tales supuestos inmigrantes mozárabes, sin descartar -al menos parcialmente y como hipótesis- un posible origen beréber o islamizado, como se sugiere para otras regiones del valle del Duero (BARRIOS I985, MAÍLLO I990).

16 Bercianos, Villagallegos, Cembranos, Zambrocinos, etc., son algunos otros lugares parameses cercanos o intercalados con los anteriores.

17 En un diploma claramente falsificado en el siglo XII en el escritorio ovetense del obispo Pelayo (GARCÍA LARRAGUETA I962, doc. n. 17; FERNÁNDEZ CONDE 1971, pp. 163-164) que intentaba así fundamentar los bienes y derechos de la iglesia de Oviedo en territorio leonés y coyantino remontándolos a los tiempos de la monarquía asturiana. La estructura de población referida a esta zona paramesa resulta anacrónica si se compara con el cuadro trazado anteriormente. Otras copias del año 906 y posteriores aparecen en Oviedo (GARCÍA LARRAGUETA 1962, doc. n. 18) y en León (SER 1981, doc. n. 5; SÁEZ I987, doc. n. 20) siempre igual de excesivas y sospechosas.

18 Los documentos de finales del siglo $X$ y primeras décadas del siglo XI muestran un mayor número de acciones (compras, ventas, permutas...) en lugares progresivamente al sur e interior de la meseta paramesa, en el entorno de Laguna, muy escasos hasta entonces. Por ejemplo, el referido del 994 (RUIZ ASENCIO 1987, doc. n. 565) relativo a Cazanuecos, Santa María la Antigua, Villamor de Laguna, Villaestrigo, Audanzas y Grajal; el del año 1002 (Ib., doc. n’. 625) en que aparecen "Uani Amores" (Benamariel) y "Uanicolues" (Benazolve) al norte de Laguna; el del 1012 (lb., doc. n. 709) en que se citan "Uilla Maiore" (Villademor?), Grajal de Ribera, Cabañeros, al este y sureste de Laguna; el del 1029 (Ib., doc. n. 855) relativo a Cazanuecos, Roperuelos, "in ualle Sancta Maria" (La Antigua), Valcabado, etc. En el 974 (SÁEZ \& SÁEZ 1990, doc. n 430 y 431) el monasterio de San Cipriano de Valdesaz de los Oteros compra varias tierras y prados "in Lacuna", aunque no hay completa seguridad de que se trate de esta Laguna de Negrillos, pues puede tratarse de algún otro de los lugares homónimos en el Páramo (hoy Laguna del Páramo, Laguna Dalga, etc.)

19 San Salvador de Negrillos es hoy un pequeño caserío abandonado, a dos kilómetros al sur de Laguna, junto al mismo arroyo de Reguerales (RODRÍGUEZ 1976 b, pp. 169-170). 
pequeño centro religioso "in territorio astoricense" que Pedro Martínez y su esposa Jimena -que lo habían edificado en su heredaddonan en 1077 al obispo e iglesia de Astor$\mathrm{ga}^{20}$. Alfonso VI y su mujer Constanza lo restituyen en 1085 a la sede episcopal de Astorga junto a otras iglesias y heredades en Galicia, Bierzo y territorio astorgano. En las proximidades de Negrillos se añaden también San Martín de Torres, Valcabado -en el Órbigo-, San Salvador de La Bañeza y San Salvador de Zotes, entre otros ${ }^{21}$. Desde entonces iría configurándose su estructura poblacional y agraria, apareciendo en la documentación los derechos sobre sus tierras repartidos entre diversos señores entre los que se encuentra la familia regia $y$ algunos monasterios ${ }^{22}$.

\section{El despunte institucional. Tenencia y alfoz de Laguna}

A mediados del siglo XII Laguna se habría convertido en uno de los múltiples centros políticos del reino leonés que van jerarquizando la red poblacional y reconfigurando el territorio en una nueva ordenación política, jurídica e institucional bajo los auspicios y autoridad del rey; a partir de Alfonso VII y, sobre todo, de Fernando II vemos aparecer estos nuevos centros a través de la presencia de tenentes o delegados regios, la dotación de alfoz o nuevo territorio al que subordinan las aldeas y población campesina del entorno, la concesión de fueros, mercado y otras regulaciones jurídicoinstitucionales (jueces, alcaldes...), exenciones y obligaciones con el monarca. Todo ello evidencia unos cambios substanciales en las relaciones sociales, afianzándose el poder del rey respecto a otros señores y a sus vasallos, así como el de los caballeros villanos respecto a aquellos y a los demás pobladores y campesinos de las villas y su alfoz ${ }^{23}$.

El primer delegado regio documentado en Laguna es Pedro Balzán, en II 64 24, a quien debió suceder Pelayo Tabladiello ${ }^{25}$. Ya en tiempos de Alfonso IX Laguna iría adquiriendo un mayor rango en la política regia, asociándose su tenencia a la de Astorga ${ }^{26}$. Ligado a la tenencia se instituye también el alfoz de Laguna ${ }^{27}$; su extensión y la relación de lugares en él incluidos, así como las obligaciones de sus habitantes con el rey y con el concejo, quedan fijadas en el fuero que unos años después concede Alfonso IX ${ }^{28}$.

El fuero ${ }^{29}$ describe con bastante minucia la delimitación del alfoz, incluyendo los términos

20 J. Rodríguez (1976 b, p. 170) afirma que ya se hallaba constituida una comunidad religiosa, pues se mencionan "monachorum ibi conmorantium".

2I FLÓREZ 1762, ap. doc. $n^{\circ}$. XX. En I I 88 y I 255 Alfonso IX y Alfonso X respectivamente confirman a la iglesia astorgana sus posesiones entre las que se cita "ecclesiam de Laguna de Nigrellis cum suis directuris" (Ib. $n^{\circ}$. XXII). La advocación a San Salvador, tan frecuente en la alta Edad Media, aparece en esta zona reiteradamente.

22 En 1 I I 5 doña Sancha donaba al monasterio de San Pedro de Eslonza heredades "inter Negrelos et Algadefe et Sanctum Salvatorem" (CALVO 1936-45, p. 287, doc. $n^{\circ}$. 103). Además, la sede asturicense tenía los derechos sobre las iglesias mencionadas anteriormente.

23 Sobre este aspecto vid. especialmente las obras de Martínez Sopena (1985, 1990, 1993, 1995).

24 QUINTANA, 1971, doc. n’. 198: "Petro Balzan tenente caliter de Lacuna de Negrillis". Poco antes el rey habría concedido la villa a Suero Rodríguez, según J. Rodríguez (1976 a y b, p. 17| y |98|, p. 19|) citando a J. González (1943, p. 47 y 365), algo que no parece ajustarse a la situación institucional manifestada en las menciones a la tenencia; en realidad J. González transcribe "Negrales" "sita in capite de Valdeviminis", que parece ser un lugar distinto de "Negrellos".

25 RODRÍGUEZ 1976a, p. 293, año 1172.

26 En I 193 tiene del rey "Alvaro Pelagii Astoricam et Negrellos" (GONZÁLEZ 1944-45, t.ll, doc. n. 62). Sobre los siguientes tenentes vid. más abajo.

27 "Alvar Pelagii tenempte Laguna cum suo alfoz" (CASADO, 1983, doc. n. 53, año I195).

28 J. Rodríguez (1976 a y 1981) deduce la fecha de concesión en 1205. Sin embargo el fuero representaría la institucionalización y plasmación jurídica de un proceso más amplio de reorganización interna de las relaciones sociales que ha comenzado antes, como vemos a través de la aparición de la tenencia y el alfoz.

29 El texto, sus versiones o traslados, así como el análisis jurídico del mismo ha sido publicado por Rodríguez (1976 a y 1981, pp. 190205 y doc. n. 58). 
y límites de cada aldea 30 ; en sentido dextrorso enumera los lindes de: $1^{\circ}$ - Laguna con Pobladura (hoy Pobladura de Pelayo García) al noroeste y norte, Toral (Toral de los Guzmanes) al este, Algadefe al sureste y Negrillos (caserío despoblado) al sur ${ }^{31} \cdot 2^{\circ}$ - de San Salvador y Conforcos con Negrillos, Algadefe, Villamandos, Cabañas y Rabines (hoy Villarrabines). $3^{\circ}$ - de Cabañeros y $4^{\circ}$ - Ribera (Ribera de Grajal) con Villamandos, Villaquejida y Marcelina (despoblado). $5^{\circ}$ - de Grajal (Grajal de Ribera) y $6^{\circ}$ Santa María la Antigua (hoy La Antigua) con Matilla (Matilla de Arzón), San Adriano (San Adrián del Valle), Dunas y Otiel (despoblado). $7^{\circ}$ - de Marcelinos (despoblado) con Fuente Adrian (San Adrián del Valle?), Matallana y Saludes (Saludes de Castroponce). $\mathbf{8}^{\circ}$ - Pozuelos (Pozuelo del Páramo) con "La Parenta e Comesajas e con Villar e con Roperuelos e con Valvacado de Cacanuecos" ${ }^{32}$. $9^{\circ}$ - de Villamayor ${ }^{33}$ con Torres (hoy San Juan de Torres), Quintana (Quintana del Marco), San Miguel de la Ryguera (hoy Regueras de Arriba y de Abajo), San Martín de Torres, Açares (Azares del Páramo), Moscas y Valcavado. $10^{\circ}$ - Villaestrigo con Negrillos y Roperuelos. $11^{\circ}$ - Torres, $12^{\circ}$ - Santa María de Cores ${ }^{34}$ y Sambroquinos (Zambrocinos) con Roperuelos, Moscas, San Pedro (San Pedro de las Dueñas), Valdefuentes, Soguillo, Santa Cris- tina y Pobladura, cerrando así el circuito en torno a Laguna.

Este alfoz comprende un radio de 5 a 10 $\mathrm{km}$. en torno a la villa de Laguna (Fig. 3), con una superficie aproximada de $15 \mathrm{~km} 2$ (unas I $5.000 \mathrm{Ha}$.), extensión semejante a la de otros alfoces próximos, como Valderas, y cercana a la media estimable para algunos otros alfoces de la cercana Tierra de Campos (MARTÍNEZ SOPENA 1985, p. 195).

En la expresión de motivos, por más que sean fórmulas muy genéricas, se encuentran algunas explicaciones significativas de la intención del monarca al conceder el fuero y derechos a los pobladores de Laguna: reorganizar el realengo y reforzar la autoridad y el poder regio frente a otros señores, mediante la potenciación jurídica y económica del concejo ${ }^{35}$, que se perfila así, a su vez, como un nuevo poder.

Como hemos expuesto, la villa de Laguna no era de nueva creación, existía con anterioridad; lo que debe entenderse por "nueva población" es su transformación en centro político con todas sus nuevas atribuciones. Igualmente fue creación nueva la morfología urbana que adoptaría la villa, con su castillo y murallas,

30 Rodríguez (198I, p. 194) observa que no delimita el conjunto del alfoz sino los catorce límites de cada uno de los lugares que comprende: "Laguna como parte con Pobladura e con Toral e con Algadefe e con Negriellos...".

31 Negrillos, el despoblado de San Pedro de Negrillos, inmediato a Laguna del que "son visibles aún los cimientos y trazados de sus antiguas casas" (RODRÍGUEZ, 198I, p. 194) formaba un pequeño núcleo inicialmente separado de Laguna por unos cientos de metros. En II 55 aún se diferenciaban Negrillos, Laguna y San Salvador (CALVO, 1957, doc. n. I03), pero desde II64 en que aparece documentada la tenencia, se menciona Laguna de Negrillos como un centro poblacional unificado. De ahí que quizás el fuero no recoga ya la entidad de Negrillos más que en la delimitación del término interno de Laguna, detalle que sorprendía a J. Rodríguez.

32 La Parenta, Comesajas y Villar son despoblados en torno a Pozuelo; creemos poder identificar Comesajas con "La dehesa de Mestajas" al noroeste de Pozuelo y Villar inmediatamente al sur, en "la dehesa del Villar", del que aún se conservan unas "Casas del Villar" y la ermita de San Tirso entre ambos. Como límite occidental de estos términos y del alfoz de Laguna se encontraría el río Órbigo, según inciden los límites que siguen en el texto foral. Valcavado y Cazanuecos son pueblos distantes unos ocho kilómetros.

33 Rodríguez cree que Villamayor puede identificarse con Villamorico, no citado en el texto y sin embargo situado en el interior del área alfocera; sin embargo los límites de Villamayor no se ajustan a la situación de este pueblo, sino más al oeste, próximos al río Órbigo; pudiera ubicarse en el término de Valcavado, en el pago de "Valdegallegos", donde aún hay alguna casa, o en Cebrones del río, más coincidente con los términos expresados.

34 Este Torres no parece ser ni San Juan de Torres ni San Martín de Torres, al otro lado del Órbigo, sino -y según la delimitación en redondo- algún caserío en torno a Zotes del Páramo. También en esa zona debió situarse Santa Maria de Cores, posiblemente en el actual pago de "los Casares", expresivo topónimo de un asentamiento despoblado; sólo una prospección más intensiva podría desvelar su ubicación precisa.

35 "Pertenesce al rey catolico dar por siempre e confirmar todos fueros e todas costumbres de derechos e toda justicia a la sua nueva poblacion por quella aproveche en valor de su concejo entre las otras viejas poblaciones... e resçiba acrescentamiento... por que ayan toda gloria e onrra de su rey, fielmente a el e todos sus suscesores presten buen serviçio..." (RODRÍGUEZ I98I, p. 173). 
que hacen suponer una planificación que afectaría no sólo al perímetro murado sino también a la distribución viaria, edificios, iglesias, plazas para realizar mercado, etc.

Como es habitual, el texto foral sienta las bases jurídicas y económicas por las que se va a regir la comunidad, regulando los derechos jurídicos, personales y fiscales de los vecinos, así como sus obligaciones fiscales y militares con el rey. El rey otorga a todos los pobladores de Laguna y de su alfoz el derecho de propiedad "por juro de heredad" sobre sus casas, viñas, tierras, palomares, etc. (art. I, según la enumeración de Rodríguez 1981), así como el derecho de sus herederos (art. 2) y la prohibición de enajenarles (art. I). Establece los derechos personales de los vecinos, así como la de extraños y siervos ajenos (art. 8); promueve la ayuda mutua y solidaridad vecinal para con los vecinos que sean vasallos de señores externos (art. 9 y I0), aún reconociendo los derechos de vasallaje hacia éstos, distinción jurídica y social que debe explicarse tanto por las desigualdades internas en el seno del concejo como por la preexistencia de derechos señoriales preestablecidos, como -por ejemplo- los del obispo de Astorga, que había obtenido de los monarcas la iglesia de Laguna ${ }^{36}$. Así mismo, se reglamenta la igualdad legislativa, judicial y fiscal de los vecinos (art. II, 25, 26), con la excepción de la participación en facenderas de clérigos (art. 26) y magistrados locales: alcaldes, corredores, escribanos y pregoneros (art. 21 ), que reciben también otras exenciones como las obligaciones militares (Id.), consolidándose así esas diferencias y desigualdades sociales. Otros preceptos inciden y regulan los derechos jurídicos de artesanos (art. 13), mer- caderes (art. 29 y 30), la paz del mercado (art. 17) y, en general, de todos los vecinos ante agresiones (art. 5, I 4 y 17), caloñas (art. 15), calumnias (art. 18), fianzas (art. 16 y 22), querellas (art. 20, 23 y 31), juicios caldarios (art. 6) e incluso embargos por el merino (art. 30). Los privilegios fiscales se concretan en la exención de portazgos, pechos y fonsaderas (art. 3), así como otros arbitrios por sello, horno o castillaje (art. 7), más la participación en recaudación de portazgos (art. 28). Las obligaciones fiscales con el rey se fijan en un monto fijo anual, proporcional al número de vecinos (art. 4), más el yantar, en maravedíes (art. 32). Las obligaciones militares se concretan en el fonsado, del que pueden excusar peones los alcaldes (art. 2I) y quienes tuviesen "tienda cabdal" (art. 19), así como en el apellido y castillaje, defensa de la villa y trabajos de fortificación en el castillo (art. 12).

El fuero, por tanto, fija la preeminencia que adquiere la villa de Laguna en las funciones políticas (tenentes, magistrados), judiciales y fiscales ${ }^{37}$, mercantiles (mercado, artesanos y mercaderes) y militares (fonsado, apellido, castillaje), tanto en el contexto del reino como respecto a las aldeas de su alfoz. Acerca de las primeras, podemos observar también por la nómina de representantes regios la pugna entre los notables por asumir e incluso por reunir varias tenencias importantes en el reino, entre las que se encontraba Laguna. Así, por el tiempo de la organización de la puebla es el propio mayordomo del rey, Fernán García, quien detenta su tenencia ${ }^{38}$. Le sucedería el poderoso magnate Rodrigo Fernández, que en los años siguientes reuniría las tenencias de Benavente, Laguna y Ponferrada ${ }^{39}$; posteriormente Fernán Tiñoso y

\footnotetext{
36 Precisamente, para compensar la posible mengua de rentas que se derivase de la creación de estas nuevas villas, el monarca hace una donación de derechos sobre las iglesias que se construyeran en tierra de Viana, Ponferrada y Laguna, en I206 (FLÓREZ I762, p. 227).

37 Posteriormente, en 1220, Alfonso IX haría donación a la orden del Pereiro y de Alcántara "in subsidium ipsius castri de Alcantara" del portazgo de San Martín de Torres, señalando los amplios términos en torno al lugar en que debería percibirse; entre tales términos se incluye Laguna de Negrillos y otros muchos lugares del Páramo y riberas del Órbigo, Jamuz y Valduerna (GONZÁLEZ 1944-45, t. II, doc. n⿳. 404, pp. 519-520).

38 "Maiordomo regis Fernan Garcia tenente Lacuna" (CASADO 1983, doc. n. 65, año 1202). Debe tratarse del mismo personaje que Gómez Moreno (1925, p. 462) llama Fernán Fernández, adelantado de Extremadura, a quien el rey encargaría las labores de organización de la puebla.

39 Vid. González (1944-45, t. II, doc. n. 231, año 1208 y doc. nº. 248, año 1209).
} 
Fernán Petri se alternan entre 1222 y 1231 40, a los cuales suceden una amplia nómina de tenentes a lo largo del siglo XIII hasta la desaparición de esta institución y la transición a la señorialización total de la villa.

La importancia estratégica de la villa en la política regia queda también de manifiesto en los años de guerra con el reino de Castilla, en los que el rey la utiliza repetidas veces como lugar residencial en la retaguardia.

\section{Fortificaciones y morfología urbana}

Es precisamente en este contexto, el de las disputas fronterizas castellano-leonesas, en el que se explica -junto al ya mencionado de reordenación territorial del reino- la importancia de las funciones político-militares de Laguna.

Aunque alejada de la frontera ${ }^{41}$ y de los principales lugares donde se desarrollan las contiendas, Laguna se encuentra a medio camino entre León y Benavente, dos núcleos vitales del reino leonés que se encontraban separados por una considerable distancia (unos 70 km); aunque en el intervalo existían otras villas y fortificaciones (Ardón, Valencia de don Juan, Castrofuerte...) parece haberse buscado un refuerzo intermedio al oeste del río Esla que -aún en la retaguardia- recibe algunos ataques en las campañas castellanas de | I88 y | 196.

Laguna es poblada en el último periodo de enfrentamientos con Castilla, después de la ruptura del Tratado de Tordehumos de I 194; en I 196 Alfonso IX, infringiendo los acuerdos de paz y la prohibición de levantar nuevos castillos, realiza una incursión en Tierra de Campos, que es contestada inmediatamente por Alfonso VIII, quien toma Castroverde, penetra hasta Benavente, Astorga y el Bierzo, volviendo hacia León y devastando algunos lugares. Esta pudo ser una de las causas inminentes de la constitución y fortificación de la puebla de Laguna; hasta entonces la villa no aparece mencionada en ninguno de los acuerdos de paz ni acciones bélicas. En la última década del siglo y primeras del siguiente Alfonso IX fortalecía la "retaguardia" fronteriza con las pueblas de Almanza, en el Cea, Rueda y Ardón, en el Esla, Castronuevo de Valderaduey, San Pedro de Latarce y Belver de los Montes, en el Valderaduey, ante la frontera castellana de los Montes Torozos (GUTIÉRREZ 1995), además de las de Villafranca, Bembibre, Ponferrada y Castroventosa en el interior (Bierzo), junto con otras en Galicia, Asturias, Extremadura y Transierra (CRÓNICA TUDENSE, ed. 1926, p. 412). Las primeras y algunas de las últimas guardan entre sí evidentes relaciones morfológicas en planta, morfología, técnica constructiva y estructuras defensivas, salvo algunas variantes debidas a condicionamientos topográficos, litología local o trazados preexistentes (GUTIÉRREZ 1995).

El propio fuero resalta claramente la importancia de construir y atender las defensas de Laguna ${ }^{42}$, que deben emprenderse en esos mismos momentos.

Desconocemos cual sería el grado de urbanismo previo a la dotación de la puebla; tan sólo percibimos que existían dos núcleos rurales

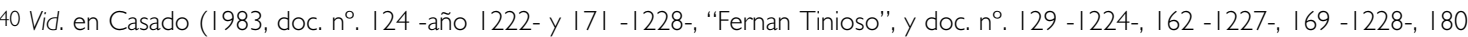
- |230-, y n. 186 -año | $23 \mid$-, "Fernandus Petri”').

41 Vid. en Gutiérrez (1995) las villas y fortificaciones de la frontera y su importancia en la política del reino. Sobre los enfrentamientos fronterizos y aspectos generales de este momento vid. especialmente González (1943, 1944 y 1960).

42 "Todos los de Laguna e de su alfoz vengan a labrar en el castillo quando fueren llamados e sy acaesçiere tiempo de guerra. Los de alfoz de Laguna vengan ayudar a los de Laguna a defender la villa para su señor, e non den portadgo de ninguna cosa que ay compraren o vendieren". Es un precepto análogo y tomado del art. $n^{\circ}$. 28 del fuero de León, si bien aquí se ha resaltado más que en aquel, anteponiéndolo a otros preceptos sobre derechos jurídicos e independizándolo de otros conceptos, además de incluir no sólo la defensa de la villa sino también las labores de construcción y mantenimiento. Muy posiblemente las "facenderas" prescritas en el texto foral fueran encaminadas a, entre otros, estos trabajos de fortificación; por otra parte, desconocemos otros detalles más precisos sobre la organización de su ejecución y financiación, ¿quizás de los mismos portazgos aludidos en el art. 28?. Vid. González Gallego (1977), Martínez Sopena (1985) o Valdeón (199I), sobre la financiación y realización de obras de fortificación en villas leonesas y castellanas.
} 
edificados, Laguna y Negrillos, ya prácticamente unidos desde el siglo XII, con una "iglesia de Laguna de Negrillos" dependiente de la sede episcopal astorgana, además del "monasterio de San Salvador de Negrillos", dos kilómetros aguas abajo.

A juzgar por el art. 4 del fuero se esperaba un crecimiento demográfico de la puebla hasta alcanzar los cuatrocientos vecinos, pero con una previsión "a la baja" -por razones fiscales- de trescientos, lo que indica que el número de habitantes iniciales sería aún menor ${ }^{43}$. Aún así se trazó un recinto amurallado de casi $9 \mathrm{Ha}$, superficie incluso excesiva para la mejor de las previsiones (400 vecinos, unos 1600 habitantes); aunque en el interior se reservasen espacios para el mercado, castillo, iglesias, plazas..., lo cierto es que debieron quedar amplios solares vacantes.

Las fortificaciones consistían en el castillo, residencia del rey o de sus delegados, y la cerca de la villa.

La cerca de la puebla se construyó en la plena Edad Media al tiempo que el castillo describiendo una planta ovalada ligeramente irregular (Fig. 4). Está construida con tapias de hormigón de cal y cantos rodados (3,2 m de anchura) de 1,25 m/hilada; aunque se encuentra muy desmontada, conserva una altura de 3 $m$ en el costado norte del castillo. El resto del recinto ha desaparecido casi por completo, pudiendo seguirse su trazado por la disposición de los viales: c/ de la Cerca, c/ de la Ronda, c/ de la Paz. En algunos tramos de la primera (al sur) y de la última (al noroeste) aparecen restos de la cerca, de escasa longitud, en las cimentaciones de las casas que se construyeron sobre ella. Tampoco se conserva ninguna de las cuatro puertas que -al menos- tendría, a juzgar por la disposición vial, situadas en los extremos de los principales ejes viales: en el eje norte-sur, cl Fray Cipriano de la Huerga (al norte) y antigua calle del Portón (al sur); en el eje este-oeste, antigua $\mathrm{cl}$ del Palacio (al este, junto al castillo) y cl Queipo de Llano (al oeste). A juzgar por la disposición radial de otras calles que parten de las plazas (plaza de San Juan, plaza del Santísimo Sacramento) pudo contar con otras puertas y portillos al noreste ( $\mathrm{c} /$ de la Cruz y $\mathrm{c}$ del Morrillo) y noroeste (C/ Calvo Sotelo).

Con unos ejes de unos $380 \times 300 \mathrm{~m}$, la puebla alcanzaría una superficie de 8,95 $\mathrm{Ha}$. La disposición urbanística en el interior del recinto trasluce aún hoy, después de una continua transformación, parte de su morfología original medieval. Además de la adaptación ovalada de las calles perimetrales a la cerca ("rondas" y calle "Honda", que quizá responda a la cárcava o foso del oeste) se aprecian aún los principales ejes viarios originales dispuestos norte-sur (este último tramo ligeramente desviado actualmente: calle del Portón o de Pedro Llanos) y esteoeste. En el centro de la villa, se emplaza la iglesia de San Juan Bautista (con trazas del siglo XIV). Ante ella la plaza de San Juan distribuye radialmente los viales hacia las salidas septentrionales; un poco más al sur otra plaza, la del Santísimo Sacramento, distribuye radialmente los viales hacia las puertas meridionales. Al exterior de estos últimos fue creándose "el Arrabal" ${ }^{44}$, recordado en el topónimo vial (C/ del Arrabal) y la iglesia de Nuestra Señora del Arrabal (siglo XVI) (GÓMEZ MORENO 1925: 463-464).

Frente a esta fisonomía intramuros, tan expresiva de la configuración medieval de la puebla, contrasta hoy el parcelario más regularizado y disperso del crecimiento moderno extramuros.

El castillo se emplaza en el centro del lado oriental, contra la cárcava del arroyo; con $32 \mathrm{~m}$ de lado cubre una superficie de poco más de

\footnotetext{
43 "...si fuere en Laguna quatroçientos vesinos o mas den a mi quinientos maravedis e denmelos por los terçios del año... E sy fuere en la puebla de Laguna mas pocos de trezientos vezinos, den en este pecho a razon de trezientos vezinos" (RODRÍGUEZ I98I, t. II, p. I75).

44 J.Rodríguez (1976, p. 176) supone que en el arrabal debió tener sus viviendas el grupo hebreo, documentado en una época tardía, a partir de 1464; sin embargo, F. Cantera (1974) lo registra en la cancillería de Sancho IV. La judería pudo ubicarse intramuros, en el sector oriental, junto al castillo, donde se mantienen los topónimos viales C/ la Cruz y C/ Santa Cruz, habituales en otras juderías. Igualmente el asentamiento próximo al castillo es común a otras muchas juderías, al ser vasallos del rey (RODRÍGUEZ I976 b).
} 
$1.000 \mathrm{~m}^{2}$. En la época inicial de la puebla la "torre mayor" debía levantarse en el ángulo suroeste; más tarde, en el siglo XV, bajo dominio de los Quiñones, una nueva torre del homenaje fue erigida en el ángulo noroeste, en ostentosa posición dominante hacia la villa. Las dos fases de construcción, que responden a iniciativas de poderes distintos (realengo y señorío) quedaron bien denotadas en fábrica y elementos arquitectónicos: la obra del siglo XIII es un recinto cuadrangular levantado con tapias de hormigón de cal y canto junto con la cerca de la villa. La reconstrucción señorial del siglo $X V$ realzó los deteriorados muros y elevó una gran torre del homenaje en el ángulo noroeste, al tiempo que añadió estancias al interior, cubos y antemural al exterior, todo ello con fábrica de mampostería (Fig. 5-8, Láms. I-7).

El recinto plenomedieval presenta una tendencia cuadrangular, aunque ligeramente trapezoidal; sus lados -con ángulos desiguales- se acercan todos a los $32 \mathrm{~m}$., si bien el ángulo sureste -redondeado- deforma o descompensa ligeramente el conjunto.

La primitiva fábrica plenomedieval es un hormigón de cal y cantos rodados, muy grueso y compacto, levantado con "tapias" de 1,25/I,40 $\mathrm{m}$ de altura (se conservan hasta II tapias en el lienzo oriental) y ligeramente ataludado (2,5 $\mathrm{m}$ de anchura en la base; $2 \mathrm{~m}$ en la primera planta). El empleo de esta técnica -tan peculiar en el reino leonés en la plena Edad Media (GUTIÉRREZ 1995)- deja algunas huellas de las "puertas" y tablazón del encofrado al exterior, hoy aún visibles (Fig. 6 y Lám. 2-3), que permiten identificar bien este tipo de fábrica. Un detalle interesante lo constituye la presencia de tramos curvos (ángulo sureste) logrado por cortas inflexiones de las "puertas"; en realidad es, pues, un ángulo multipoligonal, con apariencia global curva -más resistente- lo que da idea de la habilidad técnica de los constructores.
El acceso se situaba en el lienzo occidental, hacia la villa, donde aún hoy se aprecia un amplio boquete con restos del arco y huecos para alojar trancas. Originalmente debió carecer de torres de flanqueo; tan sólo en la esquina suroccidental, donde se engrosa el lienzo y se aprecian arranques de muros hacia el interior, pudo encontrarse una estancia más sólida, quizá la "torre mayor" del castillo plenomedieval. En el resto del patio los escombros del derrumbe impiden apreciar más construcciones.

La morfología urbana y defensiva de Laguna responde al modelo de villa fortificada extendido en estos momentos en todo el reino (GUTIÉRREZ, 1995). Especialmente significativo, además del trazado, planta, castillo y estructuras defensivas, es especialmente significativo el empleo de una genuina técnica de construcción de esta época en todo el territorio leonés: el hormigón de cal y canto; ya había sido utilizado en algunas pueblas anteriores, de época de Fernando II, como Mansilla, Villalpando, Toro - Ciudad Rodrigo, si bien predominaban entonces las técnicas terreras (cercas y motas de Bolaños de Campos, Melgar de Arriba, Villafrechós, Castroverde, Villafáfila, Coyanza o Valderas); es con Alfonso IX -y con Alfonso VIII en Castilla- cuando se generaliza su uso en León y Castilla. Se trata de una técnica rápida y económica, ya conocida desde la Antigüedad (opus caementicium), empleada en construcciones califales y almohades ${ }^{45}$, así como en algunas cristianas altomedievales, si bien es ahora cuando adopta unas características peculiares: módulo generalizado de I,40 m de altura/hilada o tapia, uso de gruesos cantos rodados, ataludamiento, coronamiento con merlones apuntados (GUTIÉRREZ 1995, especialmente pp. 6061 y 77-79). Igualmente los trazados responden a comunes características morfológicas (recintos amurallados de tendencia ovalada, con un castillo de planta generalmente cuadrangular en un lado o en un ángulo) y urbanísticas (con-

\footnotetext{
45 Las diferencias técnicas (materia prima, ejecución, módulo de tapia, etc.) son notables, a pesar de lo cual la relación con las tapias de hormigón islámico permite suponer cierta influencia o transferencias técnicas y culturales. Conocidas las relaciones que Alfonso IX mantuvo con los musulmanes en este periodo, la existencia de aljamas en Castilla y León, y las obras mudéjares que por entonces se inician en estos reinos, cabe pensar en una misma autoría mudéjar de las construcciones militares con este tipo de tapial de hormigón, también empleado en algunas iglesias mudéjares. Sin embargo carecemos de datos precisos que confirmen esta hipótesis.
} 
figuración de colaciones, barrios, iglesias, plazas, viales, mercados, etc.).

\section{Del realengo al señorío}

Después de 1230, unificados los reinos de Castilla y León bajo Fernando III, las funciones político-militares de Laguna pierden peso en el contexto de los intereses de la Corona, como las de otros núcleos similares surgidos en la frontera durante los enfrentamientos pasados. Los monarcas continúan delegando allí tenentes hasta $\left.126\right|^{46}$. Desde entonces aparece Alfonso Fernández como tenente o ya como "senor" de Laguna ${ }^{47}$. Las atribuciones y jurisdicción regia sobre la villa y su alfoz iría así como en buena parte de las villas del reinotransformándose en señorío jurisdiccional, cada vez más ambicionado por la nobleza en detrimento de la autoridad regia. Aunque en principio su ejercicio se mantiene dentro de la familia real ${ }^{48}$, las tensiones internas y la evolución jurídica hacia el señorío acabarán enajenando buena parte del poder regio ${ }^{49}$.

A lo largo del siglo XIV diversos particulares van adquiriendo propiedades en la villa y su alfoz, que acabarían -en la segunda mitad de la centuria- concentradas en manos de un poderoso magnate del momento, Pedro Suárez de Quiñones, adelantado mayor de León y Asturias. Esto supondrá la introducción de este nuevo y ascendente linaje nobiliar en amplios territorios leoneses, algunos de ellos antiguos realengos, mermando con ello la jurisdicción y rentas regias en beneficio del dominio señorial de esta "nueva nobleza".

\section{Formación del señorío de los Quiñones en Laguna}

Los intereses de los Quiñones ${ }^{50}$ en el Páramo leonés se remontan a su primer personaje conocido, Pedro Alvarez, merino mayor de Asturias, que en 1285 recibe de Sancho IV las villas de Urdiales y Santa María del Páramo, las cuales constituirán así el núcleo originario de su señorío ${ }^{51}$. Su hijo, Suero Pérez de Quiñones ${ }^{52}$, obtiene de Pedro I en 1353 el señorío y justicia de Barrientos y Posadilla -también en la ribera del Órbigo- por los servicios prestados a Alfonso XI (ÁLVAREZ 1982, p. 31). Posteriormente, como recompensa por el apoyo al bando trastámara 53 recibe de Enrique II nuevos cargos y mercedes en la tierra leonesa, en la que ejercerá el gobierno y administración de

46 Vid. por ejemplo Casado (1983, doc. n. 186, 198, 206, 218, 220, 225, 227, 238, 243, 249, 250, 286, 289, 290, 317, 320, 335, 372, 380 ), para el periodo comprendido entre $|23|$ y $|26|$, en el que se suceden - o alternan a veces- en la tenencia Fernando Petri, Rodrigo Braio, Rodrigo Fernández de Valduerna y Rodrigo Fernández Tynoso, Rui Fernández el feo y Rui Fernández Branoio, Ramiro Rodriguez y Rodrigo Fernández Brayolo, Ruy Tinoso, Do Hane y Ramiro Rodríguez.

$47 \mathrm{lb}$. doc. n. 390, 433, 497, entre 1262 y 1279.

48 En 1303 Fernando IV confirma el fuero al concejo de Laguna a petición de "doña María Fernández, ama de la reina doña María mi madre, e de la infanta doña Ysabel mi hija, cuyo es este logar sobredicho de Laguna" (RODRíGUEZ I98I, p. 190).

49 Por otra parte continúa la jurisdicción del obispado de Astorga sobre las iglesias de Laguna, confirmada en 1255 por Alfonso X.

50 Sobre este linaje, su origen, formación y evolución de su señorío, propiedades y rentas, vid. Alcedo (1918-1925), Merino (1976) y especialmente Álvarez (1982), a quien seguimos substancialmente en este capítulo.

51 ÁLVAREZ \& MARTíN 1977, doc. n. I, ALVAREZ 1982, p. 26. Carecen de validez las afirmaciones que hacen descender a los Quiñones de Rodrigo Álvarez de las Asturias, cuyo linaje se extingue a mediados del siglo XIV (MOXÓ 1969, p. I45) y con los que no se documenta ninguna vinculación (ÁLVAREZ 1982, pp. 26-27). En realidad los Quiñones proceden del homónimo solar leonés, en la ribera del Órbigo (Ib. y 1990, pp. 84-85). Su ascenso -como el de toda esa nobleza nueva- en la escala social y política del reino en los siglos XIV y XV se debe principalmente a los servicios a la Corona, el desempeño de los oficios de adelantados y merinos mayores, el oportunismo político y la vinculación -por vía matrimonial- con otras grandes familias castellanas.

52 Pedro Álvarez casó con Violante Ponce de León, iniciando así ese proceso de vinculaciones matrimoniales con otros linajes nobiliares influyentes en el reino. Su hijo, Suero Pérez, es el primer personaje del que se conocen documentalmente gran parte de sus actuaciones (ÁLVAREZ 1982, pp. 29 y ss.)

53 lb. p. 31; en su inicial etapa petrista recibe también la tenencia del castillo de Trascastro de Luna, en I359, y los oficios de Guarda Mayor, primero, y de Adelantado de León y Asturias en 1360, después de ser ejecutado el Adelantado Pedro Álvarez Osorio. Integrado desde entonces en el bando enriqueño recibe del Trastámara nuevos cargos y mercedes en tierra leonesa, ascendiendo así en la escala social castellana. Entre dichas mercedes se encuentran los lugares parameses de Urdiales, Santa María y Bercianos, que habían sido de su padre y que Pedro I había cedido a Diego González de Oviedo (Ib. pp. 3I-4I). 
justicia (lb. pp. 43-46). Esta misma línea de servicios a la causa trastámara continúa su hijo y heredero, Pedro Suárez de Quiñones, lo que le supone aumentar sus propiedades y dominios, además de la confirmación de su señorío en los lugares heredados, tanto por Enrique II como por Juan I y Enrique III (Ib. pp. 46-56).

Será en esos años finales del siglo XIV cuando Pedro Suárez comience la adquisición de propiedades en Laguna; en I391 compra a su parienta Leonor Fernández la mitad de la villa con la mitad de cada una de sus aldeas, prados y términos, por 75.000 mrs, completando en 1398 la posesión y jurisdicción al adquirir a María González de Quixada -emparentada con la anterior- la otra mitad de la villa, "con sus vasallos, casas, suelos, pastos, justicia civil y criminal en precio de setenta y dos mil maravedíes" (ÁLVAREZ \& MARTíN 1977, doc. n. 912; ÁLVAREZ 1982, p. 68). Laguna se convertiría -ya con su sucesor- en el centro señorial del amplio dominio jurisdiccional sobre el Páramo leonés, incrementado progresivamente con el concejo de Valdejamuz y otras aldeas en el Órbigo (ÁLVAREZ \& MARTíN 1977, doc. n. 706; ÁLVAREZ 1982, p. 69).

En 1398 Pedro Suárez hace testamento 54 a favor de su sobrino, Diego Fernández de Aller, hijo de su hermana Leonor Suárez, al no tener descendientes directos. Con la condición de que "tome la voz, apellido y armas de el solar de los Quiñones" le lega todos sus bienes, lugares, aldeas y vasallos, tanto los recibidos de los monarcas como los heredados de sus padres. Muerto su tío en 1402 Diego Fernández recibe también de Enrique III el cargo de merino mayor de Asturias. Su colaboración con la Corona, participando activamente en la política castellana y en las campañas militares contra el reino de Granada, llevaron a los Quiñones a sus mayores cotas de poder e influen- cia social, política y económica en la primera mitad del siglo XV (ÁLVAREZ 1982, pp. 76 y ss.). Después de obtener, en 1440 , el privilegio regio de poder fundar cuantos mayorazgos quisiera -alcanzado gracias a su habilidad política en los enfrentamientos nobiliarios de la época- instituye, al hacer testamento en 1442, cuatro mayorazgos en las personas de sus hijos Pedro, Suero, Fernando y Diego (lb. pp. 144-147). Pedro Suárez, el primogénito y legítimo heredero recibe, entre otros bienes y rentas, "la villa de Laguna con su alcazar, aldeas y jurisdiccion, de que doña Leonor de Quiñones, mi madre, me tuvo hecho donacion con Sancta María del Páramo y Breacinos (sic) 55 y Ordillo (sic), con Folleda del Páramo y de villo 56, y Villabanter, y Castrillo y San Pelayo, y San Martino del Camino y Barrientos y Posadilla con su Casa Fuerte(...)" (ALCEDO 1918, pp. 67-70). María de Toledo, esposa de Diego Fernández, recibiría en usufructo diversas rentas en dinero y especie, además de la villa de Laguna con su término, legado que volvería -a su muerte- al primogénito.

\section{La reconstrucción del alcázar}

Como hemos dicho, en la baja Edad Media y por el nuevo poder señorial se reconstruyó el primitivo castillo con distinta fábrica y se añadieron varias estructuras más, además de la torre del homenaje. Los desiguales restos del recinto, que se encontraba ya aportillado, se realzaron con mampostería ordinaria de esquistos y cantos cuarcíticos, con característico rejuntado cubriente sin llegar a revocar completamente la mampostería. Arrancan de la primera planta en los lienzos norte y sur, de la segunda planta en el paño oriental (que alcanza así $21 \mathrm{~m}$ de altura total, sobre los $15 \mathrm{~m}$ de hormigón), en tanto que en el occidental -que se encontraría más derruido- se reconstruyó desde la base, apreciándose al exterior parte de la

\footnotetext{
54 Álvarez (1982 pp. 74-76) deduce la fecha del testamento en I 398 y no en I 388 como aducían Sandoval (I600), Salazar (I694), Alcedo (1918) y Merino (1976). Por carecer de descendencia no instituye mayorazgo, lo que supondría un freno a la consolidación del señorío, en opinión de Álvarez (1982, p. 75).

55 Bercianos y Urdiales del Páramo.

56 ¿Villoria?
} 
rebaba de cimentación del hormigón. Con esta nueva fábrica se coronó el muro con adarve y parapeto almenado; los merlones son apuntados, dotados con pequeñas aspilleras en los macizos alternos. Los del lienzo occidental han sido restaurados hace unos años, alterando el orden de aspilleras. En el costado meridional no se conserva ninguno, debido al derrumbe de todo el muro de mampostería hasta la base de hormigón de cal y cantos. En el lienzo septentrional se conservan varios de ellos en desigual estado, en tanto que los trece de la cortina oriental se mantienen en su fábrica original debido a una posterior refacción del coronamiento con mampostería ordinaria de lajas y cantos sin rejuntar, que macizó y elevó el parapeto y adarve, embutiendo y "fosilizando" el almenaje anterior (Fig. 6 y Lám. 3).

La nueva merlatura - más elevada- se halla muy arruinada; sin embargo no parece haberse dotado de elementos de tiro artillero, por lo que podría tratarse de un reformado aún bajomedieval, con defensa de tiro neurobalístico como el resto del almenaje.

En una planta elevada de ese lienzo oriental, bajo el parapeto, se abrieron también vanos o ventanales, de los que parece haber carecido el primigenio recinto plenomedieval. Se encuentran justamente en el contacto entre ambas fábricas (hormigón-mampostería) a una altura considerable -a unos 15 metros- del suelo exterior (actual). Son seis vanos rectangulares de gran amplitud $(180 \times 160 \mathrm{~cm})$, que darían luz a las estancias perimetrales adosadas al interior de los lienzos, de las cuales se aprecian cajas de vigas para dos plantas en este lienzo oriental. Uno de los vanos, en el centro del paño, de menores dimensiones que los demás se cubre al interior con arco de ladrillo. Algunas aberturas más, informes, en diversos puntos de los muros parecen boquetes agrandados en tiempos más recientes.

Al interior del ángulo noreste se construyó también en la baja Edad Media una estancia o torre rectangular, más sólida y alta que el recinto -aunque se encuentra desmochada- con mampostería ordinaria y sillería de esquina, conocida como "Cubo de la reina". Monta igualmente sobre la fábrica de hormigón en el ángulo, en tanto que al interior se levanta íntegramente con la mampostería bajomedieval. Dispone de acceso elevado desde el patio, en el muro occidental, y de ventanales con molduras hacia el exterior (muros oriental y septentrional).

Cerca del ángulo suroeste, ligeramente desplazada de la esquina, se añadió una torre de flanqueo de planta semicircular, hoy mal conservada; se conoce como "Cubo de la cocina" o "Cocina del palacio". Como todo ese paño se levantó casi íntegramente de nuevo con mampostería ordinaria en el siglo XV. Mantiene su alzado parcialmente hasta el parapeto al exterior, estando derruido lo demás. Puede apreciarse un ventanal rectangular elevado en la primera planta $y$, muy arruinada, la caja de una letrina al sur, de la que aún se ve la bajante intramuros. En la planta superior conserva dos saeteras y restos de un balcón amatacanado al sur.

Al exterior del ángulo sureste se adosó otro cubo de planta ultrasemicircular, también de mampostería, macizado en la parte inferior; se encuentra desmochado, sobre él se abrió un ventanal y en lo alto del muro del recinto se aprecian restos de otra estructura muy derruida con acceso desde el adarve contiguo; quizá se tratara de un balcón amatacanado o, más bien, de un cadahalso (por los mechinales de la base), en cuyo caso debió construirse con anterioridad al cubo, el cual -situado bajo élinutilizaría su capacidad de tiro vertical.

De los dos cubos de flanqueo partían antemurales, envolviendo el recinto por el norte, este y sur. Una excavación arqueológica realizada en 1996 (VIDAL 1999: 256-257) dejó al descubierto el tramo oriental de esta barrera o antemural, construido con mampostería concertada, de un metro de anchura y separada 3'5 m del muro interior; estaba dotado -en ese tramo- de cuatro cubos, tres de ellos semicirculares y ultrasemicircular el del ángulo noreste. Al sureste se apreció también el arranque de la cerca de la villa, seccionada -como en el tramo norte- en la baja Edad Media. Posiblemente a su exterior se talló un foso, del que 
no quedan huellas; los restos de las cercas actuarían, al tiempo, como diafragmas compartimentadores de la liza entre el muro interior y el antemural.

El acceso se reharía también sobre el primitivo, en el costado occidental, hoy convertido en un boquete informe. Consistiría en una puerta simple, practicada en el muro, con arco de sillería, la cual sería arrancada, provocando el derrumbe. Sobre ella se encuentran dos escudos heráldicos con las armas de los Quiñones, veros almenados; el de la izquierda está raspado intencionadamente; el derecho muestra, además, dos motivos adicionales: disco con motivos entrelazados a izquierda y estrella de David a la derecha (del espectador) (Lám. 4).

Pascual Madoz (I847, t.X) anota la presencia de "fosos". $\bigcirc$ bien han sido totalmente colmatados o la cercanía del arroyo -en el costado oriental- motivó la impresión de su existencia. Tampoco cabe descartar que los tuviera, pues la sección producida en la cerca de la villa por el norte y sur podría responder a la excavación de la cava en la baja Edad Media, al igual que ocurriría en otras fortalezas del momento, como en el castillo de La Mota (Medina del Campo).

Pero es en la nueva torre del homenaje donde mejor se advierten las transformaciones señoriales. Si en la época de la puebla la "torre mayor" se encontraba en el ángulo suroeste, los nuevos señores trasladan la suya al noroeste, en posición amenazante hacia el interior de la villa. La reconstrucción se realizó sobre el muro de hormigón plenomedieval que se encontraba ya aportillado por debajo del adarve, detalle éste visible en la esquina noroeste, en tanto que en el resto de la torre no se ven restos del primer muro de hormigón, lo que prueba que no existía allí una torre anterior (Fig. 5-7 y Lám. I). Se levantó así una torre muy regular, de 9,4 $\times$ 9,4 m de lado (exterior), con paramentos de mampostería de cuarcita oscura con sillería de cuarcita clara y caliza en esquinas, puertas y vanos. La base del muro (2, I/ 1,85 m de anchura) se refuerza en los lados externos (norte, oeste y sur) con un zócalo de sillería, en el que son visibles algunas marcas de cantero (Fig. 9)
Se levantaron así seis alturas (Fig. 8, Lám. 5), alcanzado una altura superior a los 24 metros. Además de la imponente altura, el despliegue de elementos militares, la dotación de ostentosos ornamentos y estructuras de un mayor refinamiento palaciego -desconocidos hasta entonces-, evidencian y refuerzan el status socioeconómico de los señores.

En la planta baja tan sólo se abre una aspillera abocinada ( $|\times| \mathrm{m}$. al interior) en el lado sur, centrada y flanqueando el acceso al recinto.

En la primera planta se abren otras cuatro saeteras (al norte, sur, este y oeste, descentradas las del este y sur para cubrir y flanquear adecuadamente los lienzos del recinto), además de la puerta en el lado oriental, con una ménsula donde apoyaría una pasarela deslizante para acceder desde el adarve norte del recinto (Lám. 6). El vano de la puerta (de un metro de anchura) está abovedado y ligeramente acodado; está recercado con sillería; sobre dos impostas un arco apuntado de sillería monolítico presenta la rosca decorada con semicírculos entrelazados y secantes, con flores de lis inscritas. También el intradós se decoró con líneas longitudinales y otras transversales oblicuas. Sobre una laja horizontal -encima de la puerta- se colocó un escudo heráldico de los Quiñones (seis veros almenados con escaques).

En la segunda planta se abrió un ventanal gótico hacia poniente, con recercado de sillería al exterior ornado con arco apuntado y celosía festoneada, que se encuentra fragmentada.

En la tercera planta se practicaron tres saeteras (al este, oeste y sur, las dos primeras descentradas) y una ventanita al norte, con arco de sillería de medio punto.

La cuarta planta carece de elementos de tiro y en su lugar presenta cuatro ventanitas (una en cada lado, centradas) con arco de medio punto, con la característica sillería caliza. Desde aquí se accedía por una escalera de fábrica -practicada en el lado oriental- a la azotea, coronada con un parapeto almenado íntegramente restaurado en 197I. Antes de esa fecha se conservaban parcialmente los almenajes del 
este, sur y oeste, con los merlones apuntados muy erosionados ${ }^{57}$. En el centro de cada parapeto se colocaron otros tantos escudos heráldicos de los Quiñones y de los Toledo (escaques) alternándose; son cóncavos para ser mejor vistos desde abajo (Lám. 7). Todos los pisos y forjados -no conservados- eran de madera, a juzgar por las cajas de viguería que se aprecian en todas las plantas. El ascenso entre ellas se realizaría por escaleras también de madera, de las que se ven también algunos anclajes.

A Diego Fernández de Quiñones debe atribuirse la reconstrucción del castillo de Laguna de Negrillos. Cuando su tío, Pedro Suárez, adquiere la villa -entre |39| y |398- el primitivo castillo plenomedieval de hormigón debía encontrarse aportillado y sin uso, pues no se hace alusión al mismo ni en los documentos de compra ni en el testamento que otorga en 1398. Las primeras menciones expresas del nuevo edificio, ya con usos señoriales como casa principal de sus posesiones, aparece en 143458 . Por tanto, las obras debieron haberse realizado unos años antes, seguramente entre $\mid 407$ y 1429, época en la que Diego Fernández incrementa de manera espectacular su patrimonio y rentas y en la que emprende también la construcción y reconstrucción de un buen número de fortalezas en tierras leonesas. Por esa época construye también el torreón de Villanueva de Jamuz, con el que guarda especial relación, tanto en planta y alzado ${ }^{59}$, como en técnica constructiva (mampostería de cuarcita oscura con sillería de caliza en esquinas y recercados de puertas y vanos), elementos arquitectónicos ${ }^{60}$ e incluso la heráldica ${ }^{61}$ de Quiñones y Toledo (María de Toledo casó con Diego Fernández en 1388) que preside y certifica su autoría en ambas torres mayores.

Diego Fernández de Quiñones conocía bien las técnicas de construcción, asedio y defensa de la época, pues había participado activamente

57 Pueden observarse en algunas fotos de época anterior (PASTRANA 1976, s.p.).

58 Sentencia de Juan II contra Diego Fernández de Quiñones sobre la posesión de Cangas y Tineo: "en la villa de Laguna (...) estando este dicho dia dentro en el alcazar de la dicha villa ante el dicho señor Diego Fernández de Quiñones (...)" (ALCEDO I9I8, pp. 5666; ÁLVAREZ 1982, p. I 17). También ese mismo año de 1434, después de las justas del "Passo Honroso", Suero de Quiñones se retira unos días al alcázar de Laguna, residencia principal de la familia (PINEDA 1784, pp. 64-66; MERINO 1976, p. 55; 1979, pp. 2324; ÁLVAREZ 1982, p. 90 y 338).

59

\begin{tabular}{|c|c|c|}
\hline & LAGUNA & VILLANUEVA \\
\hline Planta & $9,4 \times 9,4 \mathrm{~m}$. & $11.9 \times 10,65 \mathrm{~m}$. \\
\hline Altura & $24 \mathrm{~m}$. & $21.8 \mathrm{~m}$. \\
\hline Anchura/muro & $1,85 \mathrm{~m}$. & $1,85 \mathrm{~m}$. \\
\hline Plantas & 6 & 5 \\
\hline
\end{tabular}

60 Especial analogía guardan las trazas, cantería y proporciones de puertas y vanos, la disposición de la puerta, con acceso elevado desde el adarve del recinto, la fábrica de muros y diseño general de ambas torres (GUTIÉRREZ I994, pp. 2I0-2 I I). Difieren en algunos elementos arquitectónicos: bóveda de cañón, ventanal con poyos o "cortejador" y matacanes en Villanueva de Jamuz. Cooper (I99|, t. I, p. 299) afirma que "las proporciones de la torre de Villanueva, sin embargo, son menos elegantes, como si fuera el prototipo". En realidad, la carencia de tales elementos "suntuosos" (cortejador, bóveda, etc.) o avanzados (matacán) en Laguna parecen indicar más bien que ésta constituye el primer ensayo o "prototipo" de torre, que desarrollarán aún más en Quintana del Marco. Además en Laguna se reconstruye sobre un castillo preexistente, al que adapta su recinto y sobre el que alza la torre mayor; en Villanueva, por el contrario, construye primero la torre ex novo, adaptando a ella posteriormente el recinto. Vid. un estudio más detallado de este castillo en Gutiérrez (1994).

61 En Laguna se colocó sobre la puerta de la torre el blasón "arcaico" " "artísticamente menos desarrollados" que los de Villanueva según Cooper (1991, p.300) de los Quiñones, con veros "en forma de doble almena, en tanto que sus sucesores los dispondrán de la manera convencional redondeada que semeja copas" (MERINO 1979, p. 19). En el parapeto se alternan los de Quiñones y Toledo (Fot. 7). Sobre la puerta del recinto se colocaron dos escudos de los Quiñones, pero de distintos "estilos y talla" (COOPER I991, t. I, p. 300); el de la izquierda muestra huellas de haber sido raspado, mientras que el de la izquierda ostenta motivos complementarios (disco con entrelazados y estrella de David), emparentados con las rosetas que acompañan al blasón de Quiñones sobre el ventanal occidental de la torre de Villanueva. Habida cuenta de que la torre del homenaje es en este lugar anterior al recinto -que se adosa a aquélla- el estilo heráldico indica que la torre del homenaje de Villanueva sería sincrónica del recinto de Laguna y -por tanto- ligeramente posterior a la torre de Laguna. Por otra parte, ignoramos el motivo de la posible execratio memoriae (i) del escudo raspado de Laguna, ¿arrepentimiento de obra o alguno de los frecuentes vaivenes de la política del momento?. Con respecto a la estrella de David, Cooper (I99I, t. I, p. 300) la pone en relación con la judería allí existente; sobre ésta vid. Rodríguez (1976 b, pp. 176-181). 
en las campañas de Fernando de Antequera contra el reino de Granada en 1407 (Zahara, Grazalema y Setenil) y en 1410 (Antequera). Sin embargo no aplica a sus construcciones leonesas todos esos conocimientos, en los que ya jugaba un papel creciente la artillería, inspirándose más bien en los modelos europeos anteriores, que representan la morada genuina de la vieja nobleza y que se extienden ampliamente por Castilla en esta época ${ }^{62}$.

El modelo se basa, pues, en el tradicional antiguo, en el que predomina la "defensa estática" sobre las innovadoras técnicas artilleras que en otras áreas ya se están introduciendo. La gran mole maciza de la torre del homenaje, realzada ostentosamente sobre el resto del recinto, con escasas aberturas de tiro (simples saeteras para armas neurobalísticas) dispuestas en las plantas bajas y coronamientos almenados en torre y recinto, supone un gran retraso técnico respecto a las soluciones artilleras, que aún tardarán unas décadas en introducirse y generalizarse en las fortalezas castellanas ${ }^{63}$. Se impone por tanto el aspecto palaciego, en el que se introducen progresivamente -como únicas novedades estructurales- algunos elementos de cierto refinamiento o confortabilidad nobiliar: en Laguna tan sólo ventanas y puertas decoradas en la torre del homenaje, letrina en el cubo suroeste.

La introducción de algunas variantes regionales -ya señaladas- propias y comunes a sus torres de Laguna y Villanueva -las más semejantes estructuralmente entre sí- así como parcialmente en las de Quintana y Ordás, permite suponer la participación de los mismos maestros de obras y canteros en las obras de Diego Fernández de Quiñones.

\section{Hacia el condado de Luna}

Con la constitución del mayorazgo principal en manos de Pedro Suárez de Quiñones, a la muerte de Diego Fernández, quedaban bajo su dominio la mayoría de los bienes del señorío familiar, integrado por bienes inmuebles en Asturias y León, además de otros menores en Valladolid y Toledo. En la tierra leonesa se extiende fundamentalmente por la montaña occidental y central (Laciana, Luna, Omañas, Ordás, Lillo), ribera del Torío y Órbigo, con un importante núcleo en el Páramo ${ }^{64}$ presidido por la fortaleza o "alcázar" de Laguna de Negrillos, que se convierte entonces en la residencia habitual de la familia, junto con la casa de Palat del Rey en la ciudad de León ${ }^{65}$.

Sin embargo, las convulsiones de la política cortesana en las que se ve inmersa Castilla a mediados de la centuria y en las cuales participan activamente los Quiñones -en el bando contrario al condestable Álvaro de Luna- motivan la prisión de Pedro y Suero de Quiñones, en 1448 , por orden de Juan II, lo que acarrea la confiscación de sus casas y fortalezas ${ }^{66}$. En agosto de ese mismo año el rey ordena la

\footnotetext{
62 Aunque sin relación directa con los hechos, el padre de Diego Fernández, Diego Fernández Vigil, fue un hidalgo y mercader aventurero que había recorrido tanto las costas mediterráneas hasta Palestina como las atlánticas de Bayona a Flandes (ALCEDO I9I8, pp. 36-40; MERINO 1976, p. 47) donde hace testamento en 1375, legando a Diego algunos castillos (Benal en la Omaña leonesa) y otros lugares en Asturias y León. A estas influencias "remotas" se unirían otras más cercanas como su experiencia militar en la guerra de Granada, sus buenas relaciones con Fernando de Antequera y los infantes de Aragón y las "modas" al uso entre la nobleza castellana.

63 Como ya hemos expuesto (GUTIÉRREZ 1994, p. 210) en el proyecto del constructor no cabría esperar enfrentamientos bélicos comparables a los de las campañas andaluzas que justificasen la introducción de grandes dispositivos pirobalísticos. Únicamente podrían inquietar a sus señores algunos levantamientos antiseñoriales, como los protagonizados por los concejos de la montaña leonesa o la guerra que desde 144 I sostienen los Quiñones contra el condestable Álvaro de Luna aunque en realidad los acontecimientos bélicos se desarrollaron en tierras castellanas más al sur de sus dominios leoneses.

64 "Este dominio señorial sobre las zonas centrales de la provincia de León en la dirección norte-sur, se hace más efectivo, si cabe por los diversos castillos, palacios, casas-fuertes, torres y alcázares que, estratégicamente situados en cada una de las zonas, intensifican la vigilancia del señor y prestan mayor seguridad a los vasallos" (ÁLVAREZ 1982, p. I46; vid. también los mapas de evolución del señorío en esta misma obra). Sobre el conjunto de fortalezas de los Quiñones vid. así mismo Álvarez (I981 y |990).

65 El castillo de Villanueva de Jamuz con su jurisdicción pasó a manos del segundogénito, Suero de Quiñones (ÁLVAREZ I982, p. I42).

66 Vid. una vez más estos avatares políticos y en qué medida afectan al señorío de los Quiñones en la indispensable obra de Álvarez (1982, pp. 154-166)
} 
entrega de los castillos de Alba de Aliste y Laguna de Negrillos, que hasta entonces no habían sido confiscados ${ }^{67}$. Los Quiñones sufrirían entonces un gran recorte en su señorío, comprometiendo su fortaleza más importante.

Pese a ello, a finales de 1450 Pedro Suárez es excarcelado, siéndole devueltas sus propiedades y $\operatorname{cargos}^{68}$. En los siguientes años se aleja de la política cortesana, muriendo poco después -en 1455, al igual que su madre María de Toledo- sin dejar testamento (ÁLVAREZ 1982, pp. 167-168). Su heredero Diego Fernández de Quiñones (segundo de ese nombre) conseguiría rehacer la casa y el señorío, recibiendo en 1462 el título de conde de Luna (lb. pp. 183-189).

Aunque desde entonces el alcázar de Laguna parece haber sido relegado por la casa de Benavides como residencia principal de los condes (Ib. p. 338), en 1468, cuando Diego Fernández -involucrado nuevamente en los bandos nobiliares contrarios al monarca, Enrique IV- reconoce a Isabel como princesa, lo hace desde la llamada "Casa-Palacio" de Laguna (Ib. pp. 204-205), donde también finalmente moriría en |49| (Ib. p. 220). Así mismo el alcaide de Laguna era, al menos en 1509, el mejor remunerado de los alcaides que los condes designaban en sus fortalezas ${ }^{69}$; $y$ en 1492 es en el "alcázar" de Laguna donde se ejecuta el testamento del segundo conde, Bernardino Fernández de Quiñones, a favor de su hijo Francisco (Ib. p. 22I). Igualmente se conocen los jueces que ponen en la villa los condes de Luna (Ib. pp. 307 y 309).

Por consiguiente, todo parece indicar que la fortaleza de Laguna seguía siendo la más prestigiosa de la casa condal, a pesar del paulatino debilitamiento de ésta a partir de 1480 (Ib. pp. 220 y ss.). Los continuos conflictos tanto con otros señoríos nobiliarios como con la propia monarquía proseguirían en las décadas siguientes, aminorando progresivamente el poder del condado. A la muerte del segundo conde, en 1492, incluso se ve amenazado su señorío en Laguna por la intromisión del vecino -y ahora rival- condado de Benavente; aprovechando la debilidad de los Quiñones construía en 1493 una fortaleza en el cercano lugar de Ribera de Grajal, desde donde hostigaba con sus gentes a los vecinos de Laguna, motivando la intervención de los reyes (RODRíGUEZ 1976 b, pp. 174175). Ya en 1516 el conde se vio nuevamente envuelto en las rebeliones contra la Corona, siendo la fortaleza de Laguna de nuevo asediada y tomada por los oficiales de la reina (ÁLVAREZ \& MARTín 1977, doc. n. 477).

Las noticias posteriores son muy escasas y confusas, insuficientes para conocer el posterior uso y destino de la fortaleza, como el de la misma casa condal, que acabaría integrada en el condado de Benavente en I585 (MERINO 1976, p. 40). Desconocemos, así mismo la época concreta en que se recreció el adarve del recinto (visible aún hoy en el lienzo oriental) que embutió el almenaje apuntado de la reconstrucción emprendida por el primer Diego Fernández Quiñones. Posiblemente se deba a su sucesor, Pedro Suárez, o a alguno de los primeros condes de Luna -aún en la segunda mitad del siglo XV-, pues es improbable que una reforma posterior a esa época (por ejemplo, bajo el tardío dominio de los condes de Benavente) no introdujera ya un moderno parapeto artillero.

67 lb. pp. 164-165. Según P. Carrillo de Huete, en su Crónica del Halconero (ed. 1946, pp. 503-504) estando el rey en Medina de Rioseco acude hasta allí María de Toledo, "cuya era la dicha Laguna" (en usufructo según el testamento de Diego Fernández) para asegurar al rey la entrega de esa fortaleza, accediendo Juan II a que mantuviese todos sus derechos en la villa. Sin embargo, según la Crónica de don Álvaro de Luna (ed. 1940, pp. 215-216) fue necesario que el rey llegara hasta la casa de Laguna, que no se quería entregar al enviado regio, para que los hombres de los Quiñones depusieran su actitud, dejando allí el rey a su alcaide.

68 A comienzos de 145 I aparece de nuevo como "merino mayor de Asturias, señor de la villa de Laguna" (Crónica de don Álvaro de Luna, ed. 1940, p. 448).

69 "Argote, allcajde de Laguna. Tiene de tenencia este año con la fortaleza de Laguna, XX mill. (mrs.) e XL cargas de pan moreno e (C) cargas de vino..." (ALCEDO 1918, pp. 154-158). Sobre las funciones de los oficiales nombrados por los condes en sus villas, concejos y fortalezas, vid. nuevamente Alvarez, 1982, pp. 302 y ss. 
Igualmente se nos escapa el momento final de la ocupación del castillo y las circunstancias posteriores hasta llegar a su actual estado de abandono y ruina progresiva.

\section{CONCLUSIONES}

Como hemos visto, una primitiva aldea altomedieval surgida en el proceso de colonización feudal fue elevada en la plena Edad Media a la categoría de villa como apoyo y refuerzo del realengo. La nueva villa o "puebla" real dotada de fuero, un nuevo término o alfoz, tenente o delegado regio, nuevas instituciones concejiles, mercado y un nuevo estatuto de población, forma parte de una "red" de villas o centros de población que reordenan el territorio y jerarquizan el entramado poblacional urbano y rural del reino de León, siguiendo un modelo ampliamente extendido no sólo en el reino y norte peninsular sino en toda la Europa feudal. El poder del rey sale fortalecido frente al de otros poderes (señoríos laicos y eclesiásticos, monarquías feudales de Castilla y Portugal), estableciéndose o instituyéndose además nuevas relaciones y categorías jurídicas entre los pobladores de la villa, tanto hacia el rey y otros señores como hacia los pobladores del alfoz adscrito o sometido al señorío colectivo de la villa. La nueva situación configura además una morfología o fisonomía urbana propia de las pueblas de este momento: recinto amurallado de la villa, con el castillo en un extremo, albergando iglesias, parroquias, barrios o collaciones, mercados y demás dotaciones de la población.

En la baja Edad Media la villa y su alfoz, como tantas otros del reino, caen progresivamente bajo el dominio de la poderosa nobleza emergente después de la crisis castellana de mediados del siglo XIV. La familia de los Quiñones extiende sus propiedades por el Páramo leonés haciéndose con el dominio y jurisdicción de éste y otros lugares y habitantes que antes dependían de la Corona. Además del cambio de relaciones sociales y políticas, y de situación jurídica de los pobladores con los nuevos señores, éstos convierten a Laguna en su centro de residencia desde donde ejercen su señorío jurisdiccional en las tierras llanas del Páramo leonés. Esto conlleva la transformación morfológica de la villa y sobre todo de su castillo, que reconstruyen introduciendo en él elementos propios y característicos de la época y de la clase social que lo detenta.

Esta evolución del territorio, la morfología urbana y arquitectónica, tan expresiva de los cambios en las relaciones sociales y en el ejercicio del poder, quedó bien reflejada tanto en la constitución del concejo y el alfoz como en los restos constructivos del castillo, cercas y entramado urbano de la villa, por lo que su estudio arqueológico informa de modo gráfico y expresivo de tales transformaciones.

\section{BIBLIOGRAFÍA}

ALCEDO Y DE SAN CARLOS, M. de, 19|8-25, Los Merinos Mayores de Asturias del apellido Quiñones y su descendencia. Apuntes genealógicos, históricos y anecdóticos, 2 vols., Madrid.

ÁLVAREZ \& MARTÍN 1977: ÁLVAREZ ÁLVAREZ, C., MARTÍN FUERTES, J.A., 1977, Catálogo del Archivo de los Condes de Luna, León.

ÁLVAREZ ÁLVAREZ, C., 1981, Castillos medievales leoneses de la Casa Condal de Luna (I350-1500), Estudios Humanísticos, 3, pp. |4|-152.

ÁLVAREZ ÁLVAREZ, C., 1982, El Condado de Luna en la Baja Edad Media, León.

ÁLVAREZ ÁLVAREZ, C., 1990, Castillos, palacios y torres de los Quiñones en la baja Edad Media leonesa, Castillos medievales del reino de León, Madrid, pp. 83-100.

BARBERO, A., VIGIL,M. 1978: La formación del feudalismo en la Península Ibérica, Barcelona.

BARCELÓ, M. et alii 1988: Arqueología medieval. En las afueras del "medievalismo", Barcelona.

BARRIOS 1985: BARRIOS GARCÍA, A., 1985, Repoblación de la zona meridional del Duero. Fases de ocupación, procedencias y distribución espacial de los grupos repobladores, Stvdia Historica. Historia Medieval, vol. III, n'. 2, pp. 33-82.

CALVO 1936-45: CALVO Y TORBADO, A., 1936-45, El Monasterio de Gradefes: apuntes para su historia y la de algunos cenobios y pueblos del Concejo, León. 
CANTERA, 1974: CANTERA, F, 1974, Juderías medievales de la actual provincia de León, Archivos Leoneses, vol. XXVIII, n. 55-56, pp. 85-I55.

CARRILLO DE HUETE, Crónica del Halconero, ed. 1946:

CARRILLO DE HUETE, P., Crónica del Halconero de Juan II, ed. por J. de Mata Carriazo, Madrid.

CASADO 1983: CASADO LOBATO, C., 1983, Colección diplomática del Monasterio de Carrizo. León, León.

COOPER 1991: COOPER, E., 1991, Castillos señoriales en la Corona de Castilla, Junta de Castilla y León, 3 t.

Crónica de don Álvaro de Luna, ed. 1940: Crónica de don Álvaro de Luna, Condestable de Castilla, Maestre de Santiago, ed. de Juan de Mata Carriazo, Madrid.

CRÓNICA TUDENSE, ed. 1926: Crónica de España por Lucas, Obispo de Tuy, ed. J. Puyol, Madrid.

ESTEPA DÍEZ, C. 1977: Estructura social de la ciudad de León (siglos XI-XIII), León.

ESTEPA DÍEZ, C. 1984 a, 1984, El alfoz y las relaciones campo-ciudad en Castilla y León en los siglos XII y XIII, Stvdia Historica. Historia Medieval, vol. II, n. 2, pp. 7-26.

ESTEPA DÍEZ, C. 1984 b, El alfoz castellano en los siglos IX al XIII, En la España Medieval, IV, t. I, pp. 305-34I.

FERNÁNDEZ CONDE 197।: FERNÁNDEZ CONDE, F.J., 197I, El Libro de los Testamentos de la Catedral de Oviedo, Roma.

FLÓREZ 1762: FLÓREZ, H., I762, España Sagrada. De la Santa Iglesia de Astorga, Madrid, t. XVI.

GARCÍA LARRAGUETA 1962: GARCÍA LARRAGUETA, S., 1962, Colección de documentos de la Catedral de Oviedo, Oviedo.

GÓMEZ MORENO 1925: GÓMEZ MORENO, M., 1925, Catálogo Monumental de España. Provincia de León (19061908), Madrid.

GONZÁLEZ, J., 1943, Regesta de Fernando II, Madrid.

GONZÁLEZ, J., 1944-45, Alfonso IX, Madrid.

GONZÁLEZ, J., 1960, El Reino de Castilla en la época de Alfonso VIII, Madrid.

GONZÁLEZ GALLEGO 1977: GONZÁLEZ GALLEGO, I., 1977, Las murallas y los puentes de León en el siglo XIV, León y su historia, IV, pp. 365-4II.

GUTIÉRREZ GONZÁLEZ, J.A. 1985: Poblamiento antiguo y medieval en la montaña central leonesa, León.

GUTIÉRREZ GONZÁLEZ, J.A. 1989: Sistemas defensivos y de Repoblación en el reino de León, III CAME, Oviedo, $|7|-|9|$
GUTIÉRREZ GONZÁLEZ, J.A. 1994, El castillo de Villanueva de Jamuz (León). Un ejemplo de fortificación innovadora a mediados del siglo XV, Estudios de Historia y de Arqueología Medievales, X, Cádiz, pp. 199-233.

GUTIÉRREZ GONZÁLEZ, J.A. 1995, Fortificaciones y feudalismo en el origen y formación del reino leonés (siglos IXXIII), Valladolid.

GUTIÉRREZ GONZÁLEZ, J.A. 1996: El Páramo leonés entre la Antigüedad y la alta Edad Media, Stvdia Historica. Historia Medieval, 14, 47-96.

GUTIÉRREZ GONZÁLEZ, J.A. 1997: Expansión y consolidación feudal del reino de Asturias: las fortificaciones de Alfonso III en la montaña leonesa, Homenaje a Juan Uría Riu, Oviedo, t.l, 275-300.

GUTIÉRREZ GONZÁLEZ, J.A. 2000: Sobre la transición al mundo medieval en el valle del Duero. Nuevos planteamientos desde la arqueología del territorio, I Simposium de Arqueología Medieval. Homenaje al Prof. Manuel Riu, Barcelona (e.p.)

GUTIÉRREZ GONZÁLEZ, J.A. 200 I: Dominio político y territorio en la formación del Feudalismo en el norte peninsular. Propuestas y reflexiones, $V$ Congreso de Arqueología Medieval Española. Valladolid 1999, Junta de Castilla y León, Valladolid, 629-655.

MADOZ 1847: MADOZ, P., I 848- 1854, Diccionario Geográfico-Estadístico-Histórico de España y sus posesiones en Ultramar, Madrid, 16 vols.

MAílLO SALGADO, F., 1990, Los árabes en la Meseta Norte en el periodo emiral y califal, Las tres culturas en la Corona de Castilla y los sefardíes, Salamanca, pp. 243-253.

MARTÍNEZ SOPENA, P., 1985, La Tierra de Campos occidental. Poblamiento, poder y comunidad del siglo X al XIII, Valladolid.

MARTÍNEZ SOPENA, P., 1990: Las Pueblas reales de León y la defensa del reino en los siglos XII y XIII, Castillos medievales del reino de León, Madrid, I I3-137.

MARTÍNEZ SOPENA, P., 1993: Las repoblaciones de Castilla y León: organización del espacio y cambios sociales entre los siglos X y XIII, III Curso de Cultura Medieval. Seminario: Repoblación y Reconquista, Aguilar de Campoo, 57-64.

MARTÍNEZ SOPENA, P., 1995: Repoblaciones interiores, Villas Nuevas de los siglos XII y XIII, Despoblación y colonización del valle del Duero, León, |6|-|87.

MERINO RUBIO, W., 1976, Diego Fernández de Aller y la constitución del patrimonio territorial de los Quiñones, Tierras de León, 24, pp. 40-56.

MERINO RUBIO, W., 1978: Toponimia mozárabe en la Repoblación del territorio leonés, León Medieval. Doce estudios, León, pp. 43-57.

MERINO RUBIO, W., 1979, Castillos del Passo Honroso. Laguna de Negrillos y Villanueva de Jamuz, Castillos de España, 17, pp. |3-3|. 
MÍNGUEZ 1980: MÍNGUEZ FERNÁNDEZ, J.M. 1980: El dominio del monasterio de Sahagún en el si-glo X. Paisajes agrarios, producción y expansión económica, Sala-manca.

MOXÓ 1969: MOXÓ, S., 1969, De la nobleza nueva. La transformación nobiliaria castellana en la baja Edad Media, Cuadernos de Historia. Anexos de Hispania, 3, pp. 1-210.

PASTOR, R. 1980: Resistencias y luchas campesinas en la época del crecimiento y consolidación de la formación feudal. Castilla y León, siglos X-XIII, Madrid.

PASTOR, R. 1994: Formación y consolidación del feudalismo castellano-leonés. Siglos X-XIII, Los orígenes del Feudalismo en el mundo mediterráneo, Granada, I 19-139.

PASTOR DÍAZ DE GARAYO, E. 1996: Castilla en el tránsito de la Antigüedad al Feudalismo. Poblamiento, poder político y estructura social. Del Arlanza al Duero (siglos VII$X I)$, JCL, Valladolid.

PASTRANA 1976: PASTRANA GARCÍA, J., 1976, Castillos Leoneses. La Bañeza, s.l.

PINEDA 1784: PINEDA, J.F., I 784, Libro del Passo Honroso defendido por el excelente caballero Suero de Quiñones, Madrid.

RODRÍGUEZ 1948: RODRÍGUEZ, R. 1948: Catálogo de Documentos de Santa María de Otero de las Dueñas (Archivo Espiscopal de León), León.

RODRÍGUEZ FERNÁNDEZ, J., 1964, El Monasterio de Ardón. Estudio histórico sobre los centros monásticos medievales de Cillanueva y Rozuela, León.

RODRÍGUEZ FERNÁNDEZ, J., 1972, Ramiro Il, rey de León, Madrid.
RODRÍGUEZ FERNÁNDEZ, J., 1976 a, Fuero de Laguna de Negrillos, Archivos Leoneses, n. 59-60, pp. 29I-316.

RODRÍGUEZ FERNÁNDEZ, J., 1976 b, Las Juderías de la provincia de León, León.

RODRÍGUEZ FERNÁNDEZ, J., 1981, Los Fueros del Reino de León, León, 2 vols.

RODRÍGUEZ FERNÁNDEZ, J., I 982, Ordoño III, León.

RUIZ ASENCIO 1987: RUIZ ASENCIO, J.M., 1987, Colección Documental del Archivo de la Catedral de León (775|230). III (986-|03|), León.

SÁEZ 1987: SÁEZ, E., 1987, Colección Documental del Archivo de la Catedral de León (775-1230). I (775-952), León.

SÁEZ \& SÁEZ 1990: SÁEZ, E., SÁEZ, C., 1990, Colección Documental del Archivo de la Catedral de León (775-1230). II (953-985), León

SÁNCHEZ-ALBORNOZ, C., 1966, Despoblación y Repoblación del Valle del Duero, Buenos Aires.

SÁNCHEZ-ALBORNOZ, C., 1976, Sobre la libertad humana en el reino asturleonés hace mil años, Madrid.

SER 198I: SER QUIJANO, G. del, 198I, Documentación de la Catedral de León (siglos IX-X), Salamanca.

VIDAL 1997: VIDAL ENCINAS, J.M., 1997, León, Nvmantia. Arqueología en Castilla y León 1995/I996, 7, pp. 245266

VALDEÓN 1991: VALDEÓN BARUQUE, J., I991, Reflexiones sobre las murallas urbanas de la Castilla Medieval, La Ciudad y las murallas, Madrid, pp. 67-87. 


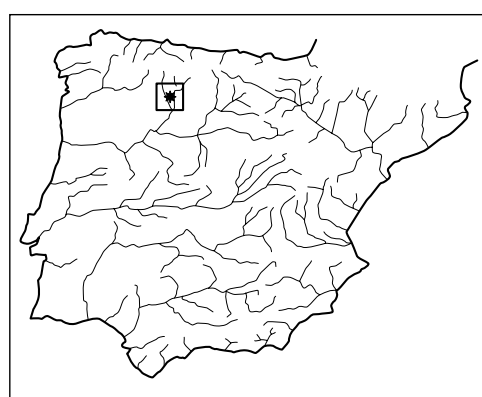

Fig. I. Situación de la Laguna de Negrillo en el Páramo Leonés

Fig. 2. El Páramo Leonés. Poblamiento Antiguo y Medieval (Gutiérrez 1996)

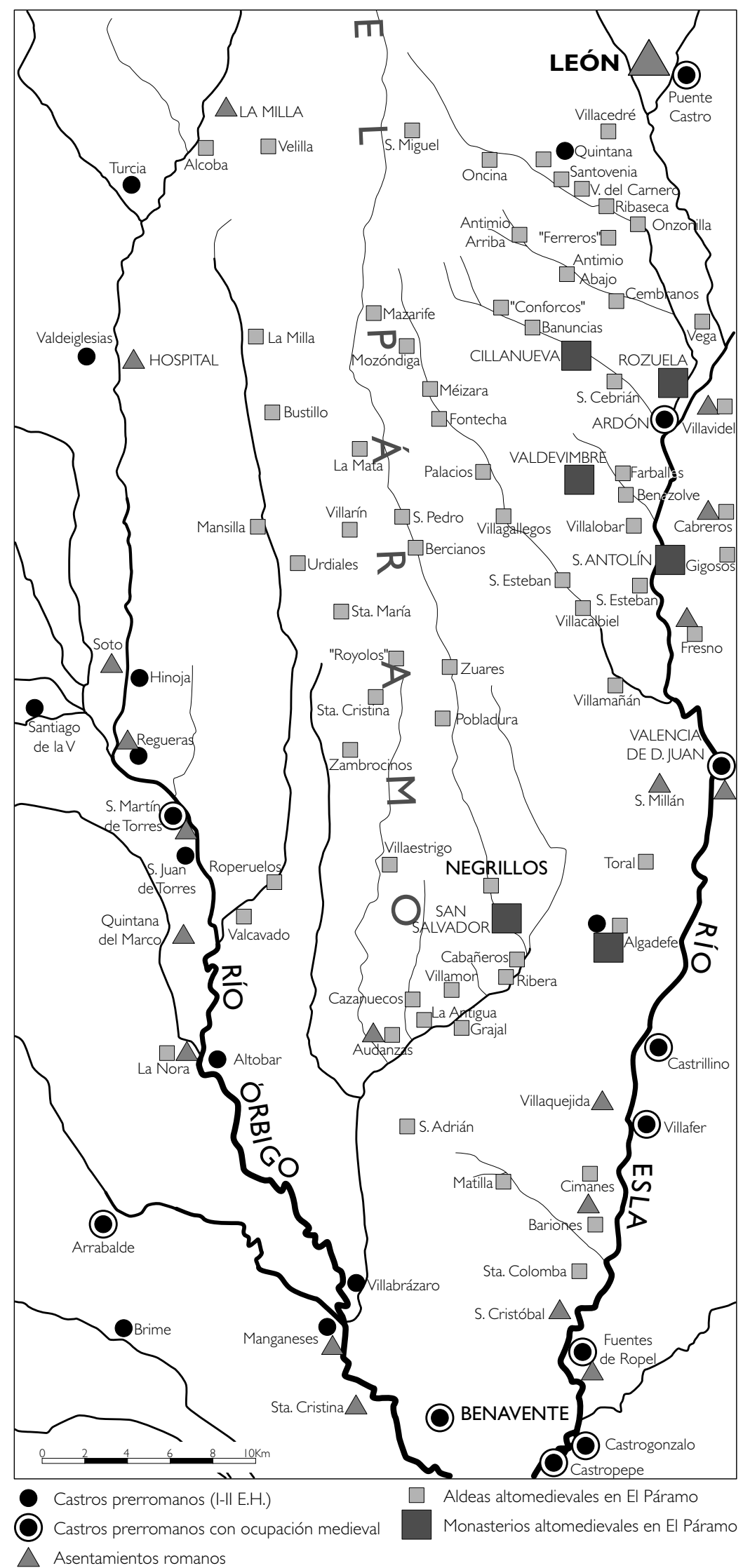




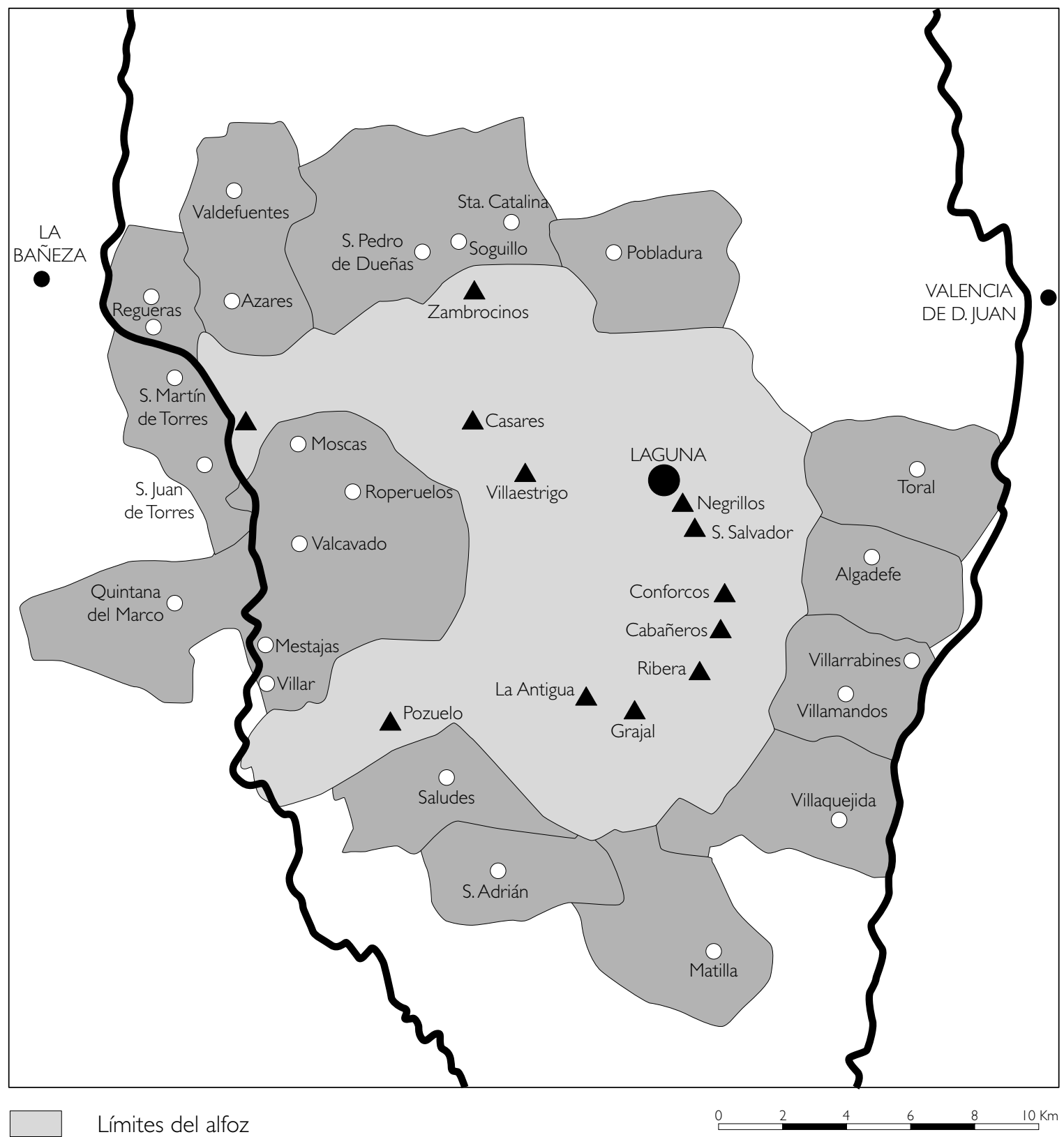

Términos exteriores

- Aldeas alfoceras

- Aldeas linderas

Fig. 3. El Alfoz de Laguna 


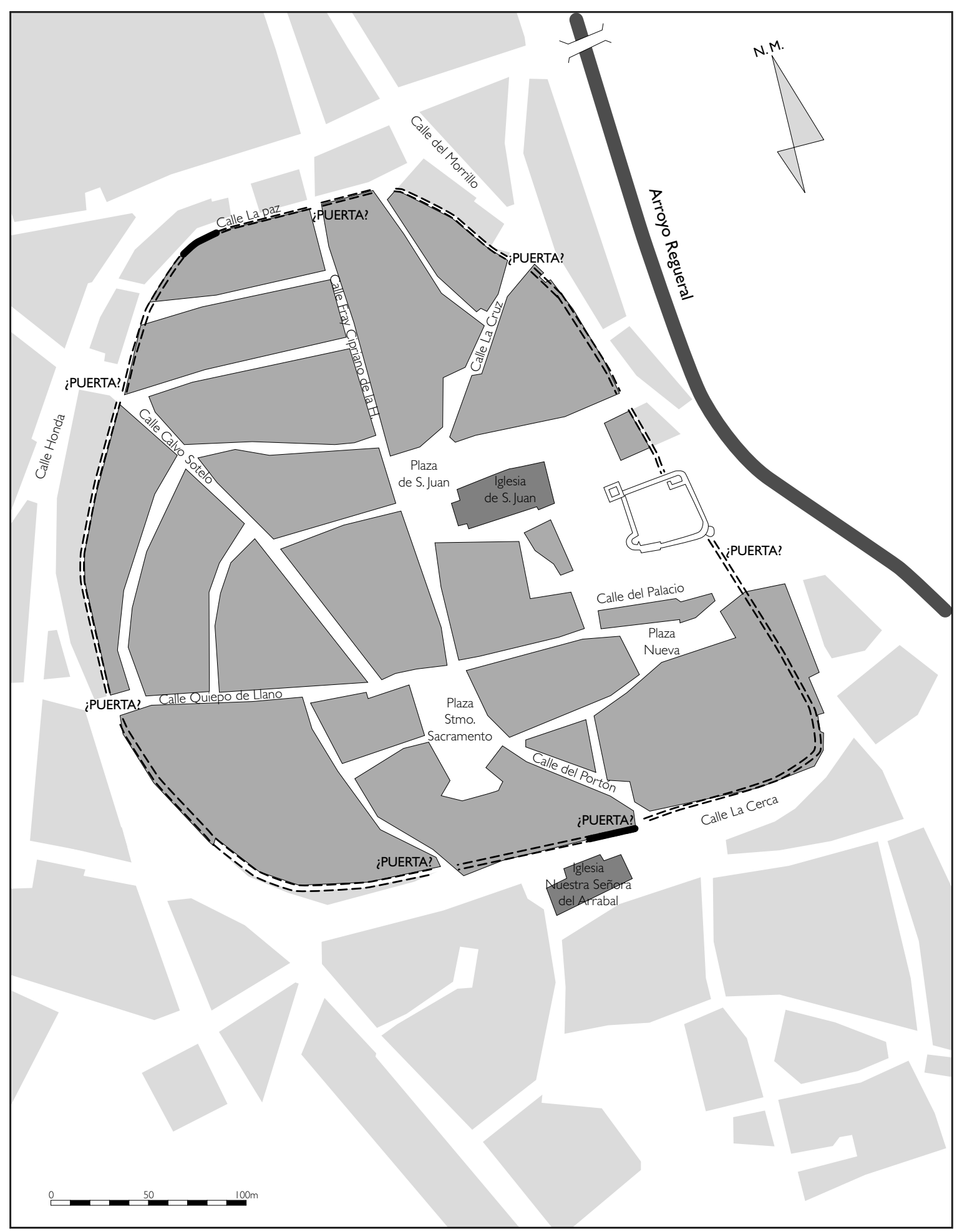

Fig. 4. La Villa de Laguna de Negrillos. Situación del castillo y cercas con restitución hipotética de puertas, sobre el parcelario moderno 


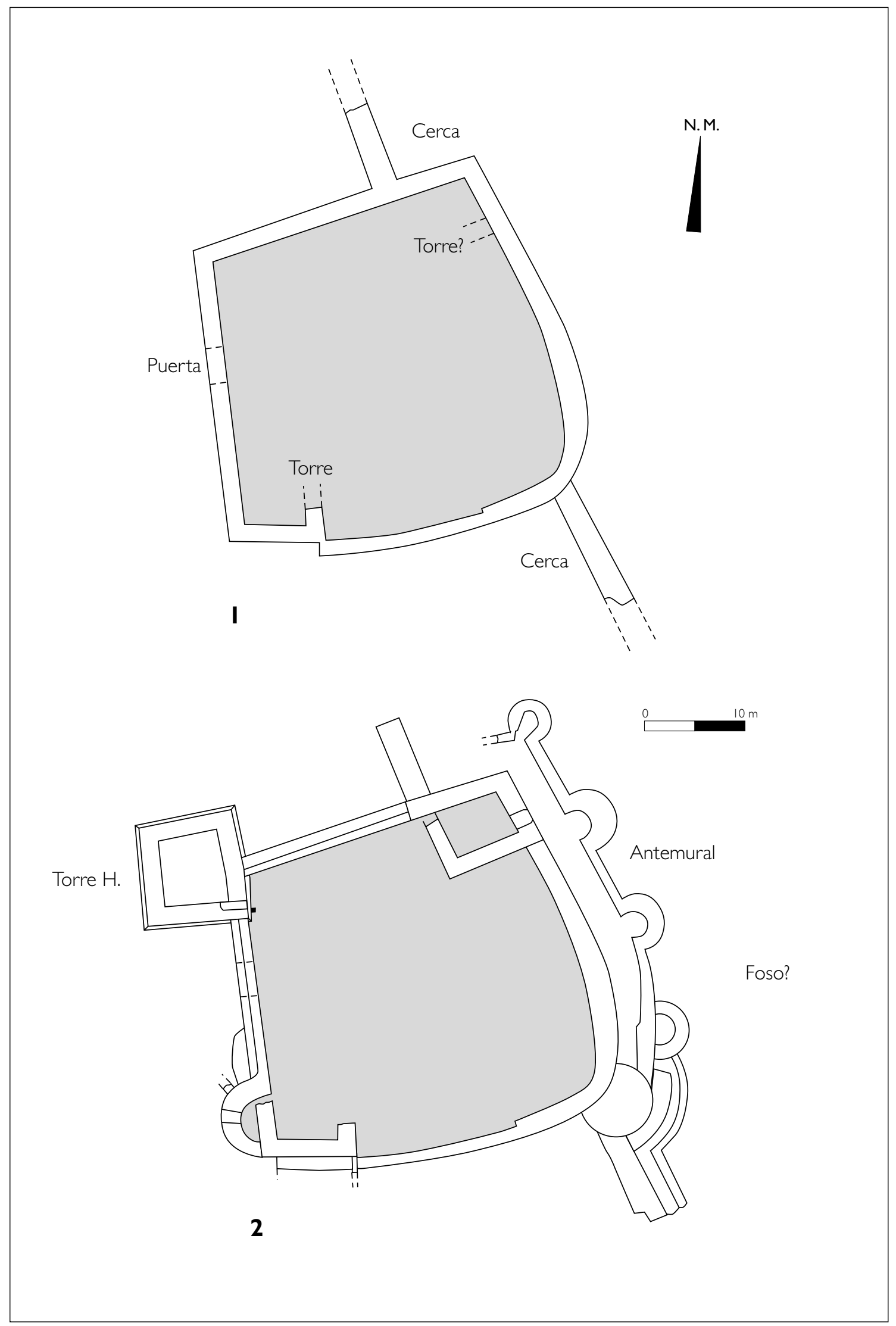

Fig. 5. El castillo de Laguna de Negrillos. Plantas básicas

1. Planta plenomedieval

2. Planta bajomedieval 


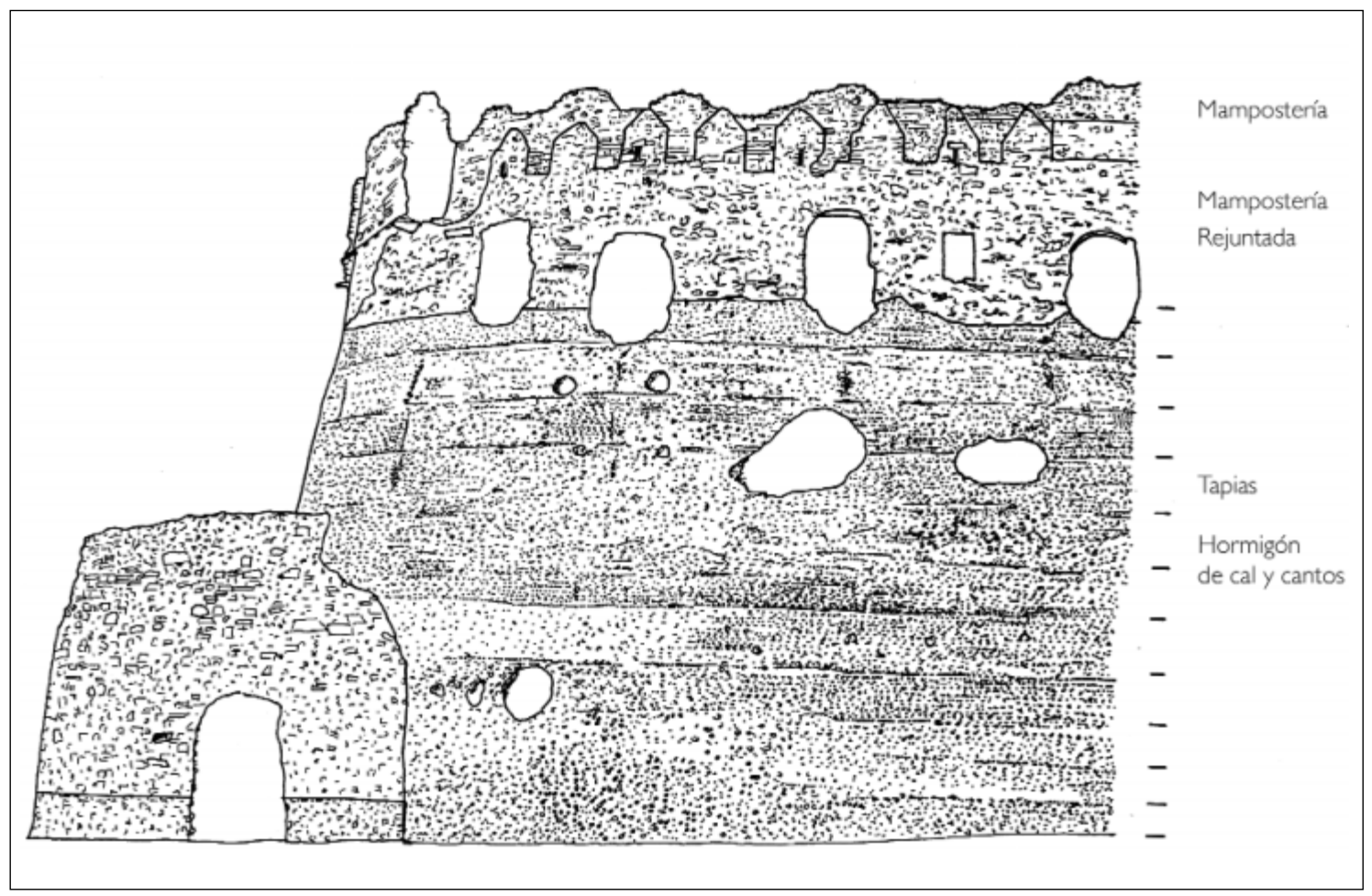

Fig. 6. El Castillo de Laguna de Negrillos. Alzado oriental. Superposición de fábricas y recrecido del adarve de mampostería rejuntada con mampostería ordinaria

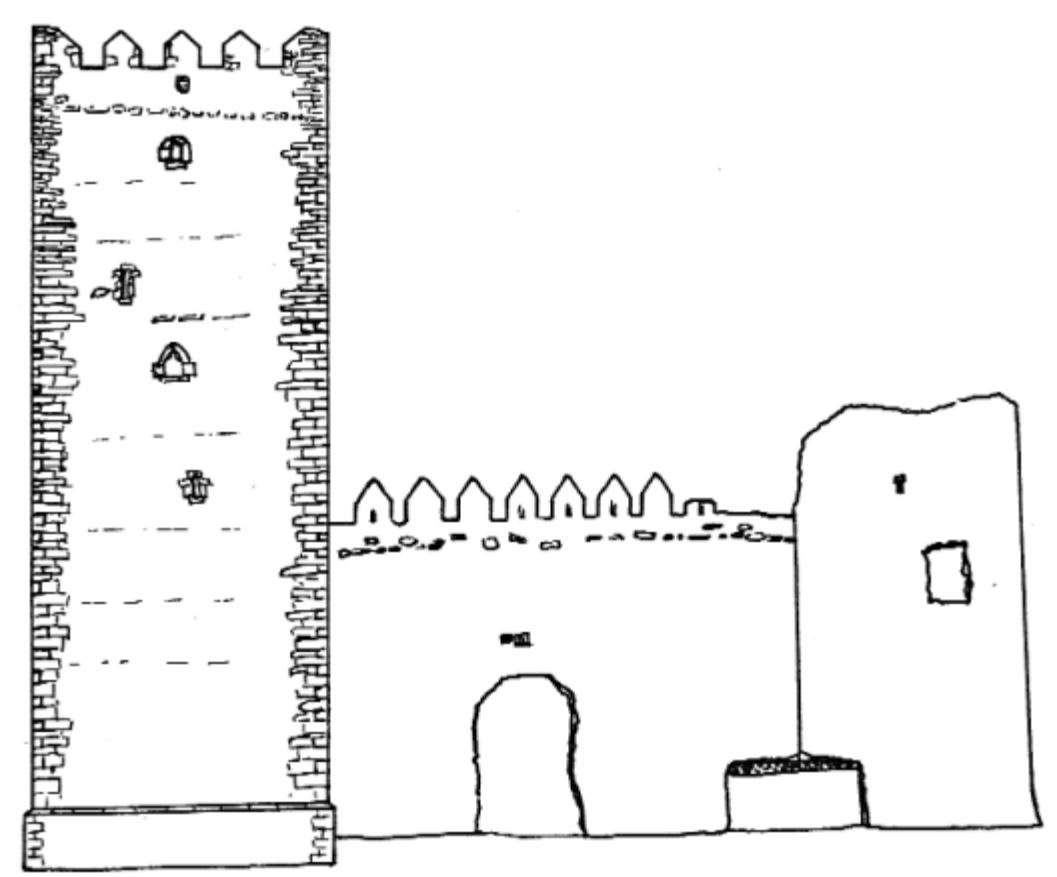

Fig. 7. El castillo de Laguna de Negrillos. Alzado occidental. 


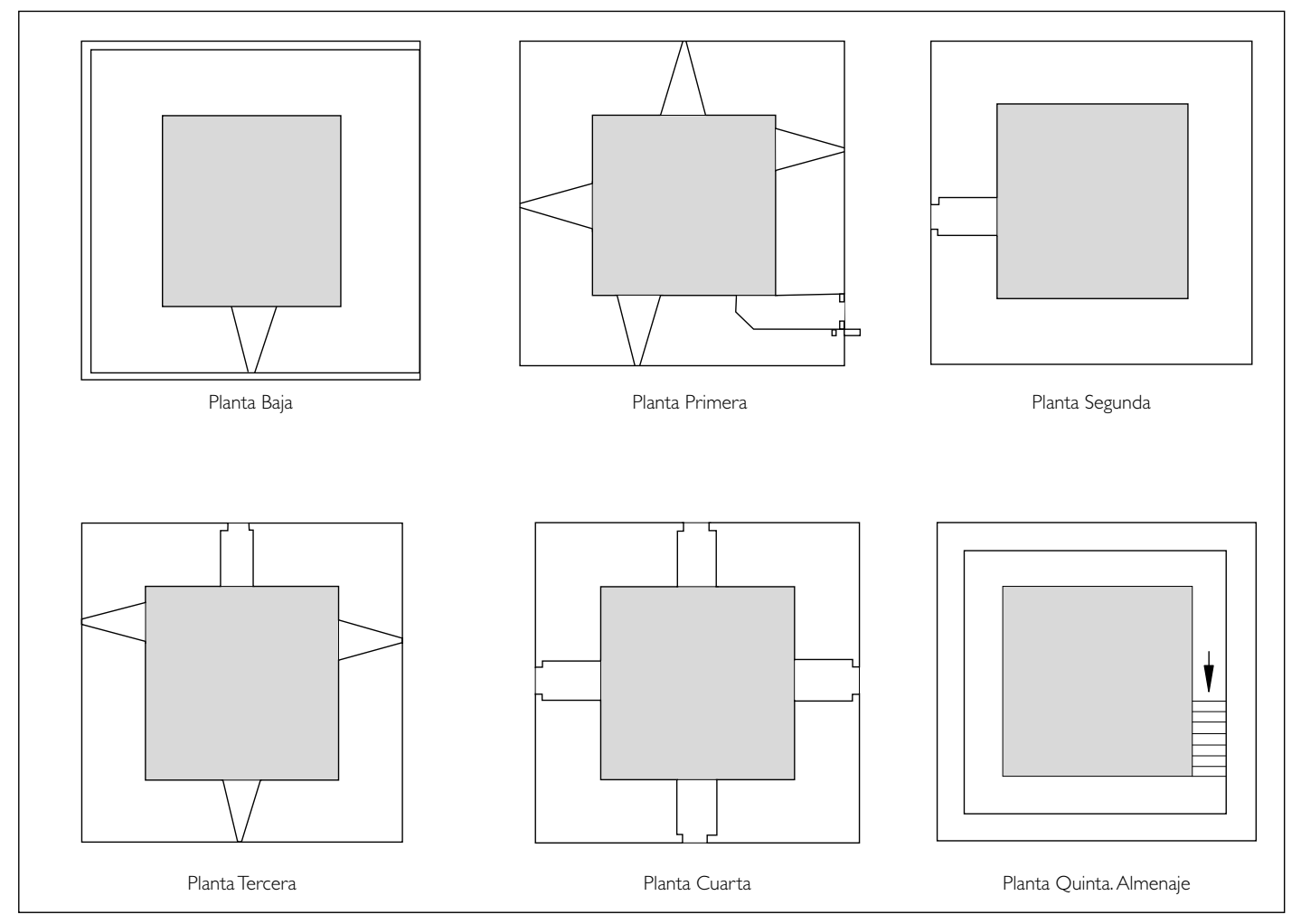

Fig. 8. La torre del homenaje. Plantas básicas

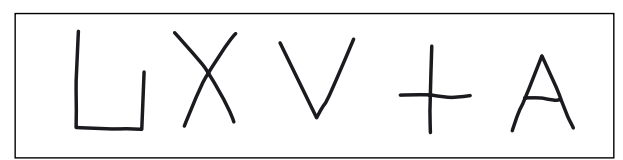

Fig. 9. Marcas de cantero en sillares de la torre del homenaje

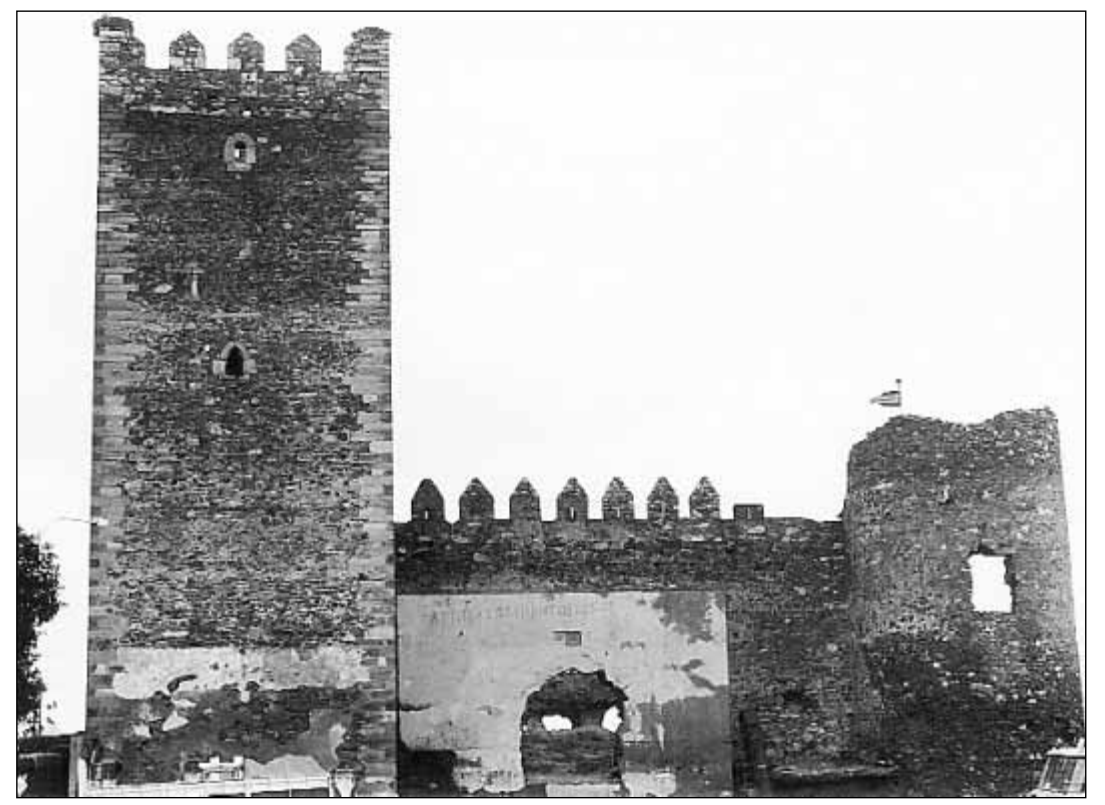

Lám. I. Castillo de Laguna de Negrillos. Costado occidental: torre del homenaje, lienzo con acceso y cubo suroeste 


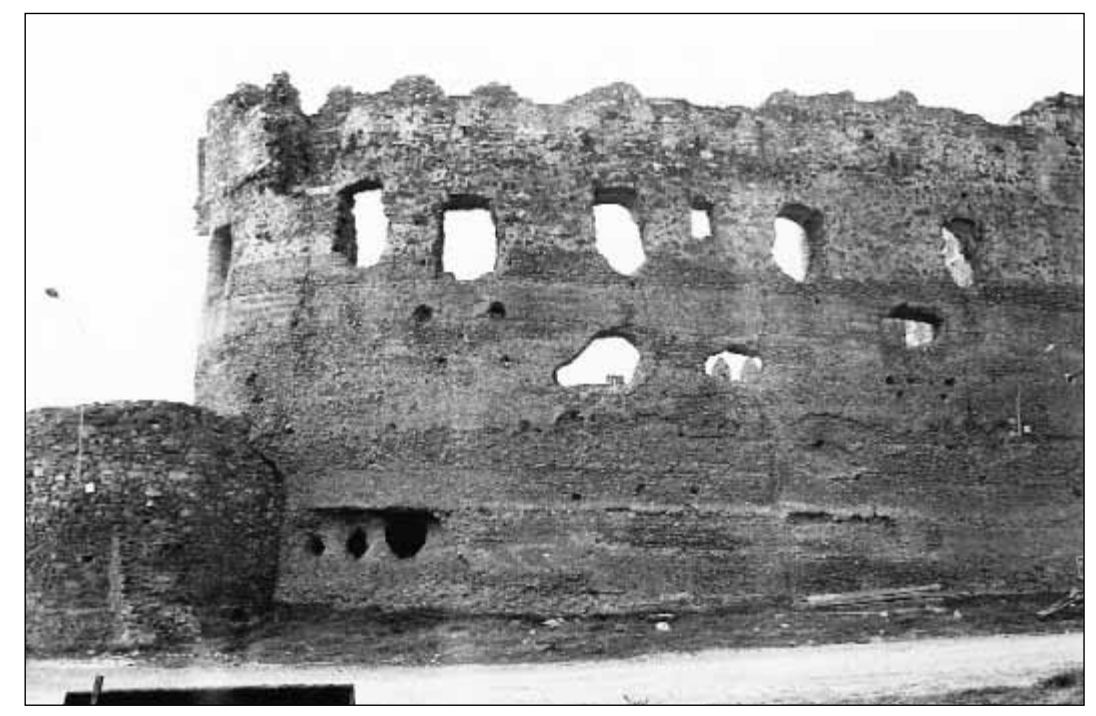

Lam. 2. Exterior del lienzo oriental y cubo sureste

Lam. 3. Lienzo oriental. Superposición de fábricas: recrecido con mampostería ordinaria del adarve bajomedieval de mampostería rejuntada superpuesto al hormigón plenomedieval
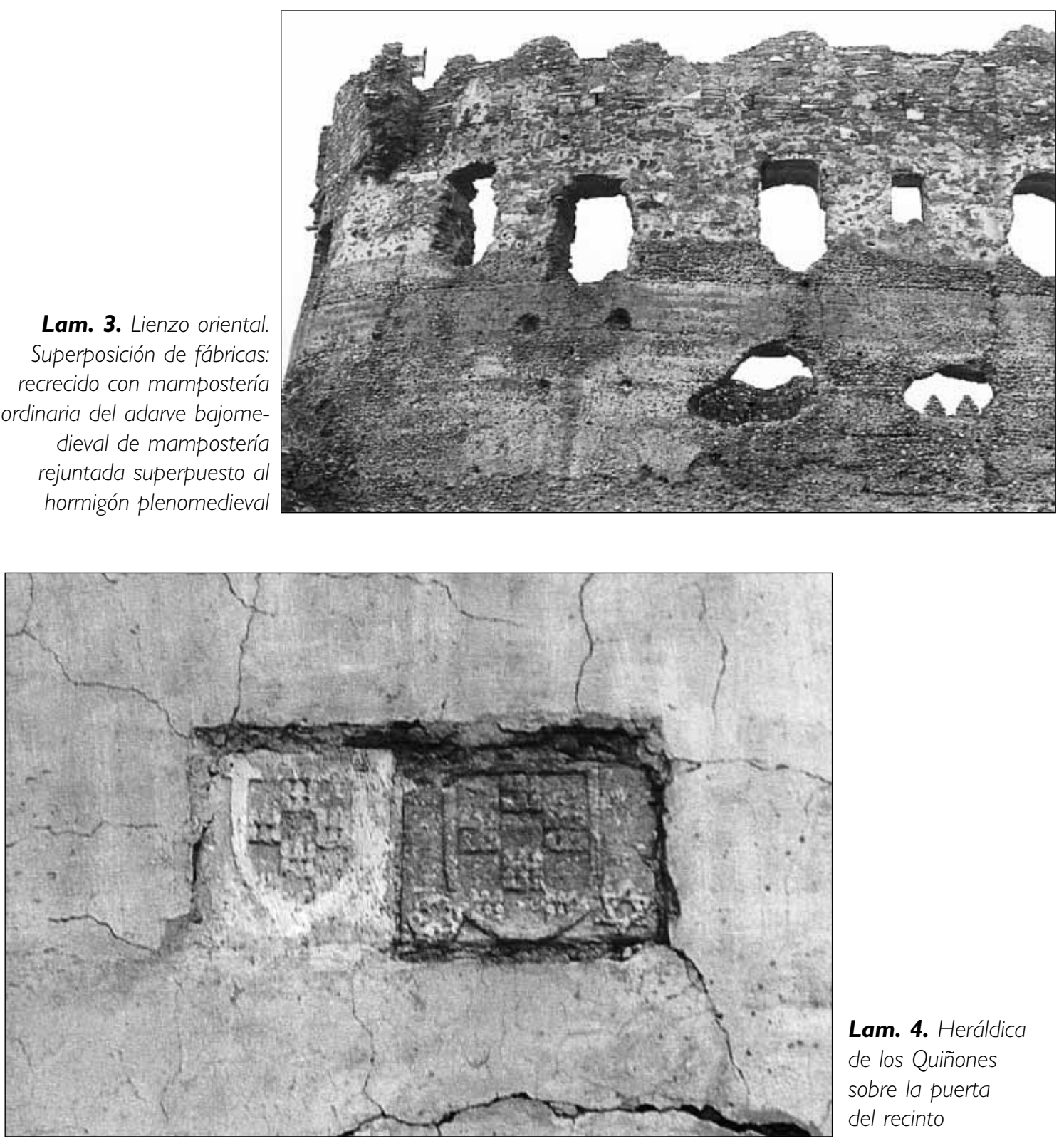

Lam. 4. Heráldica de los Quiñones sobre la puerta del recinto 


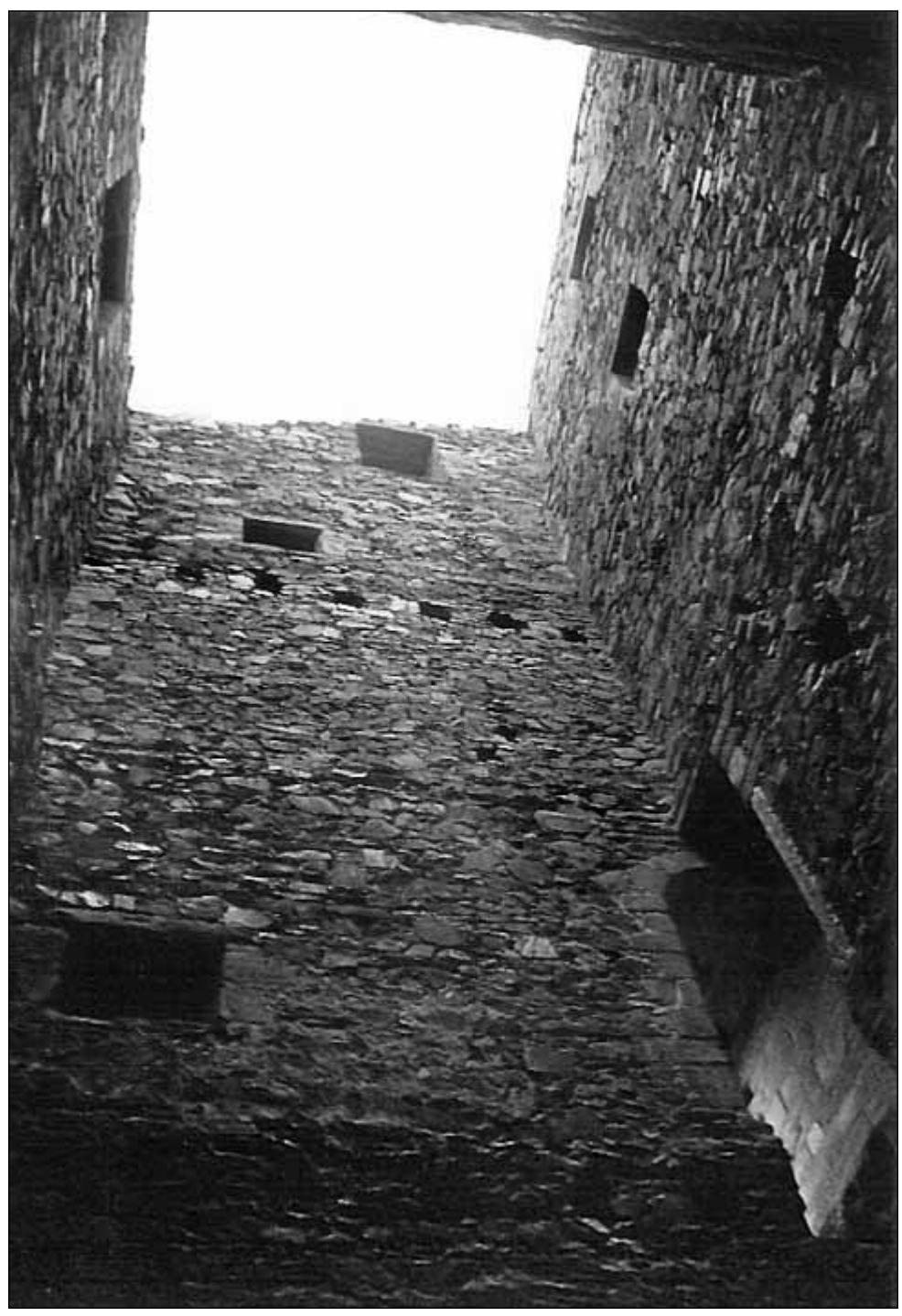

Lám. 5. Interior de la torre del homenaje. Frente oriental 


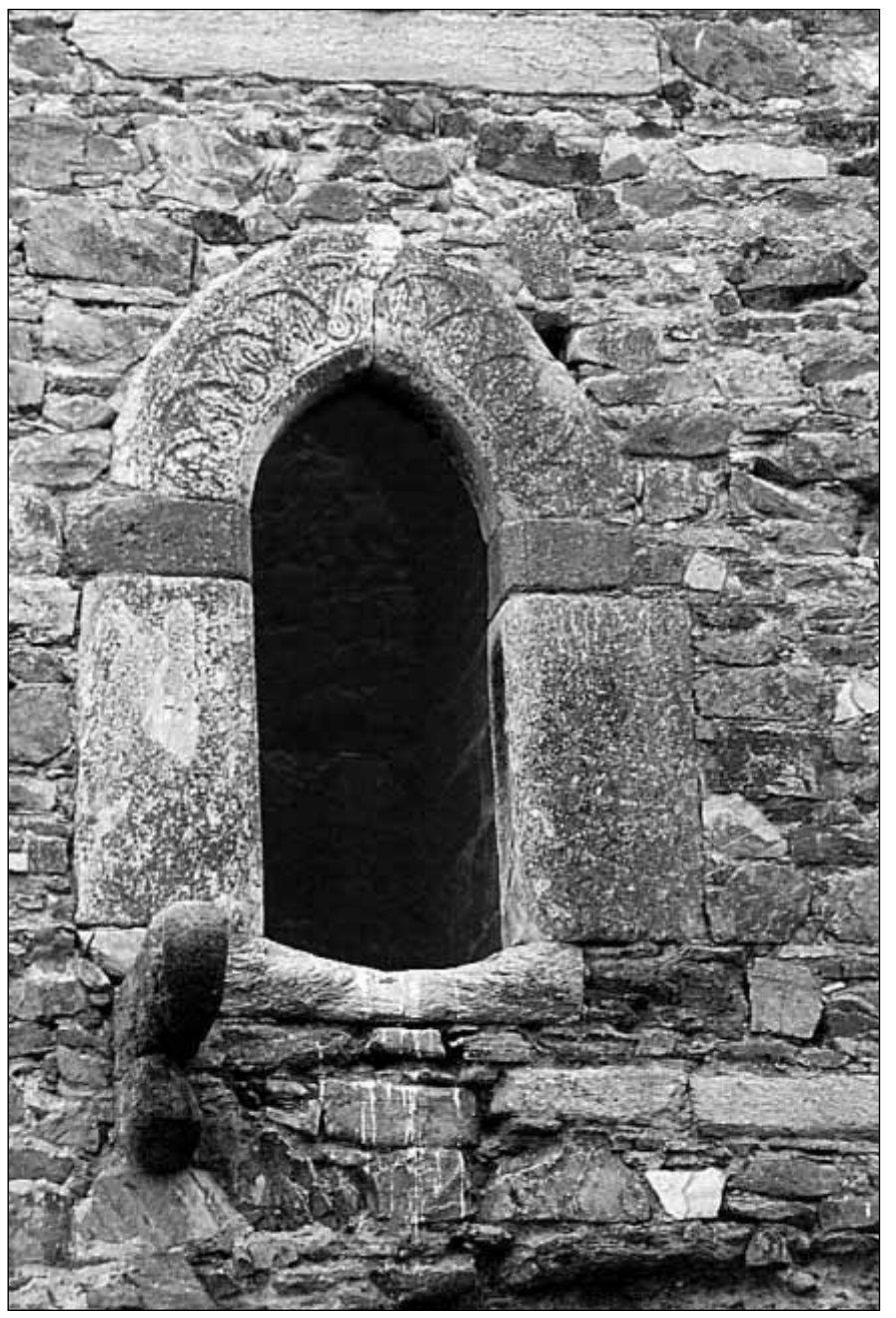

Lám. 6. Acceso a la torre del homenaje:

puerta con arco decorado, ménsula

Lám. 7. Torre del homenaje. Parapeto almenado restaurado, con blasones cóncavos de los Quiñones y Toledo

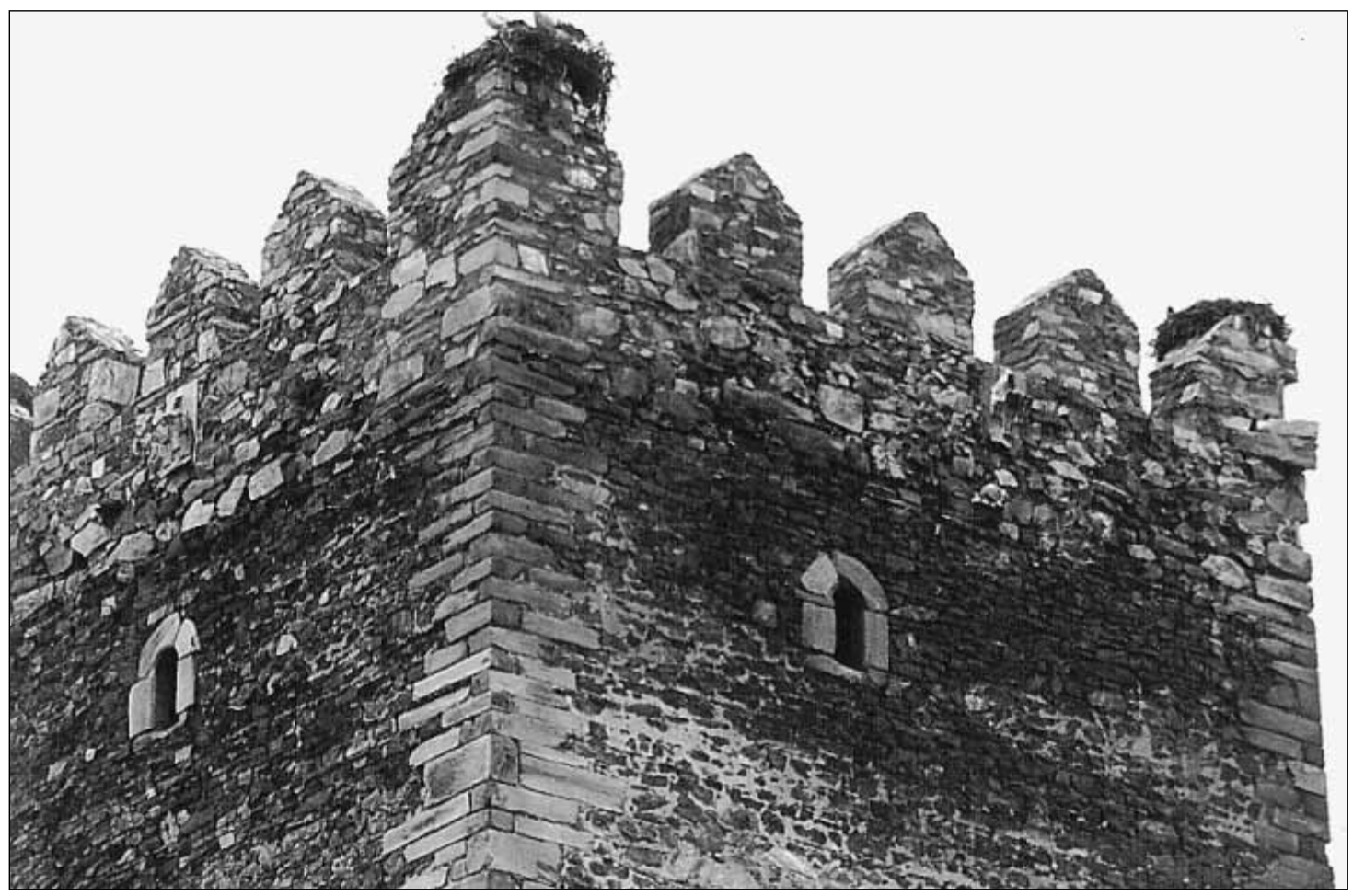

